\title{
Total Synthesis and Structure-Activity Relationship Studies of the Cytotoxic Anhydrophytosphingosine Jaspine B (Pachastrissamine)
}

\author{
Srinath Pashikanti ${ }^{1}$ \\ Rehnman Ukani \\ Sunil A. David ${ }^{2}$ \\ Apurba Datta*
}

Department of Medicinal Chemistry, The University of Kansas, 1251 Wescoe Hall Drive, Lawrence, KS 66045, USA adutta@ku.edu

Dedicated to Professor Hiriyakkanavar Junjappa on the occasion of his $80^{\text {th }}$ birthday
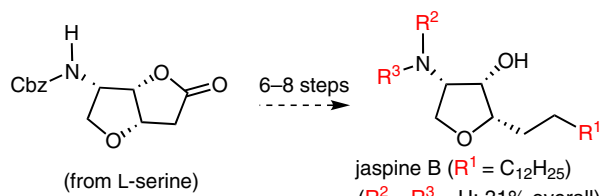

jaspine $\mathrm{B}\left(\mathrm{R}^{1}=\mathrm{C}_{12} \mathrm{H}_{25}\right)$ $\left(\mathrm{R}^{2}=\mathrm{R}^{3}=\mathrm{H} ; 31 \%\right.$ overall) and 13 analogues (22-47\%)
Received: 09.09.216

Accepted after revision: 16.11.2016

Published online: 19.12 .2016

DOI: 10.1055/s-0036-1588118; Art ID: ss-2016-m0623-op

Abstract By utilizing an L-serine-derived bicyclic lactone as an advanced chiral building block, a short synthetic route to the cytotoxic marine natural product jaspine B has been developed. Targeting structure-activity relationship investigations, the synthetic route has also been utilized for the synthesis and cytotoxicity evaluation of strategically modified jaspine B analogues. In addition, a previously reported synthesis of the title natural product from our research has been reinvestigated to clarify the sterochemical assignment.

Key words jaspine B, stereochemistry, cytotoxic, drug development, structure-activity relationships

The marine natural product jaspine B (Scheme 1), also known as pachastrissamine, was isolated independently from two different sponges Pachastrissa sp (2002), ${ }^{3 a}$ and Jaspis sp (2003). ${ }^{3 \mathrm{~b}}$ The all-syn-trisubstituted tetrahydrofuran framework of this novel compound represents the first example of a cyclic anhydrophytosphingosine structural feature in a natural product. In biological assays, jaspine B exhibited submicromolar cytotoxicity $\left(\mathrm{IC}_{50} \leq 0.5 \mu \mathrm{M}\right)$ against several different cancer cell lines. ${ }^{3}$ It was shown to inhibit murine B16, and human Sk-Mel28 melanoma cells in a time- and dose-dependent manner. Exposure of these cells to jaspine $B$ triggered cell death by typical apoptosis, as indicated by phosphatidylserine externalization, the release of cytochrome $c$ and caspase processing. ${ }^{4}$ It has been inferred that interference with ceramide metabolism via inhibition of sphingomyelin synthase is probably responsible for the apoptotic effects of this natural product. ${ }^{4}$ In further support of the above mechanistic pathway, jaspine B-induced cell death was enhanced in cells deficient in sphingomyelin synthase, whereas, in human cells overexpressing sphingomyelin synthase, cell death was strongly inhibited. ${ }^{4}$ In more recent studies, it has also been reported that jaspine $B$ is an inhibitor of sphingosine kinases 1 and 2 (Sphk1 and SphK2), and atypical protein kinase C. ${ }^{\text {a }}$ In another mechanism of action study, jaspine B-induced apoptosis in melanoma cells has been attributed to inhibition of cyclindependent kinase 2 ( Cdk2) production, and extracellular regulatory kinase (ERK)-mediated down regulation of FOXO3. ${ }^{\text {b }}$ Since its isolation, the interesting structural features and exciting anticancer potential of jaspine $B$ have made it a popular target for synthesis, resulting in a number of publications reporting an impressive array of total synthetic routes to this bioactive natural product. ${ }^{6,7}$ In contrast, studies aimed at identification of the essential pharmacophore of jaspine B, and correlating its structural features with biological activity are still evolving, and represents a research area in need of further investigation. 6,8

In a continuation of our long-standing interest in the synthesis and structure-activity relationship (SAR) studies of jaspine $B$, here we describe the development of a total synthetic route to jaspine $B$, and further application of the method in strategic structural modification studies of the C2 and C4 substituents thereof (Scheme 1).

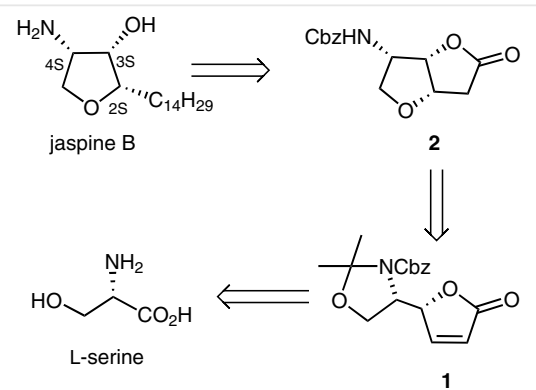

Scheme 1 Jaspine B: Structure and retrosynthetic strategy 
Additionally, with a view to clarifying some conflicting reports, ${ }^{6 \mathrm{~b}, 7 \mathrm{k}}$ we have also reinvestigated a previously reported jaspine B synthesis from our research ${ }^{9}$ (see below), and the results of the study reported herein.

Soon after the isolation and biological activity of jaspine B were reported, we undertook a preliminary study aimed at the total synthesis of this bioactive natural product. The retrosynthetic strategy for the intended synthesis envisioned utilization of the L-serine-derived chiral aminobutenolide 1 (Scheme 1), a previously developed 'chiron' from our research, ${ }^{10}$ as a strategic chiral platform towards rapid construction of the all-syn 2,3,4-trisubstituted structural framework of jaspine $B$.

Thus, starting from aminobutenolide $\mathbf{1}$, a two-step reaction sequence involving selective cleavage of the $\mathrm{N}, \mathrm{O}$-acetonide linkage and exposure of the resulting $\mathrm{N}$-Cbz-aminoalcohol to mild basic conditions resulted in a clean and stereoselective formation of the bicyclic lactone $\mathbf{2}$ (Scheme 2). The stereochemistry at the newly formed chiral center is attributable to the energetically favorable formation of the cis-fused [5,5]-bicyclic ring junction. Attempting to install the $\mathrm{C}_{14}$-alkyl chain as in the natural product, partial reduction of the lactone to lactol 3 and its subsequent condensation with a $\mathrm{C}_{12}$-alkyl donor Wittig reagent led to the olefin derivative $\mathbf{4}$ as an $E / Z$-isomeric mixture. Interestingly, during this reaction process, the secondary alkoxide ion (at C3) generated in situ was found to collapse on the neighboring carbamoyl moiety at $\mathrm{C} 4$, forming a skeletal rearranged cyclic carbamate. Finally, hydrogenation of the olefin providing the required C2-tetradecyl analogue $\mathbf{5}$, and alkaline cleavage of the cyclic carbamate culminated in the purported synthesis of jaspine $B$.

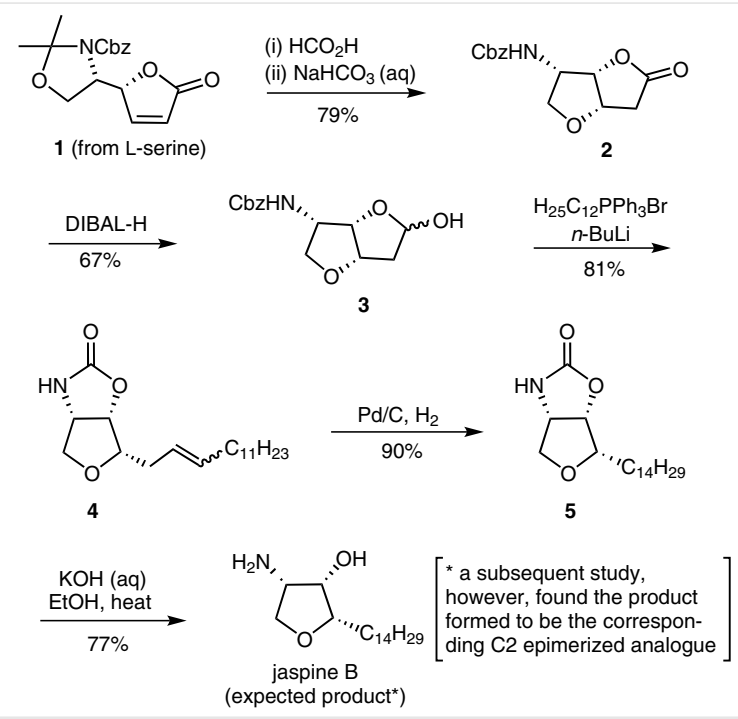

Scheme 2 Our previous approach to jaspine B ${ }^{9}$
In the 2005 publication $^{9}$ reporting the results of our above synthesis, the stereochemistry of the final product was assigned as the (expected) natural $(2 S, 3 S, 4 S)$ absolute configuration. However, in a surprising development, a subsequent study $(2008)^{6 c}$ by Davies and co-workers revealed that the product obtained during our above synthesis was not the all-syn natural jaspine B as reported, but the corresponding C2-epi analogue thereof. This reassignment of the above stereochemistry was based on comparison of the spectroscopic data of jaspine B and the C2-epimer, as available from several studies published subsequent to our report. ${ }^{6 c}$ To rationalize the formation of this unexpected product, Davies also suggested an alternative reaction pathway, wherein the transient aldehyde intermediate 6 formed in situ (Scheme 3) from the lactol $\mathbf{3}$ under the base-promoted Wittig olefination conditions, could have undergone a C2 epimerization via a retro-Michael-Michael addition sequence (in a $\beta$-elimination followed by recyclization process), resulting in the sterically more favorable C2-C3 trans-tetrahydrofuran aldehyde intermediate 8. ${ }^{\text {cc }}$ Subsequent transformations involving this $(2 R)$-aldehyde 8 ultimately led to the formation of 2-epi-jaspine B.
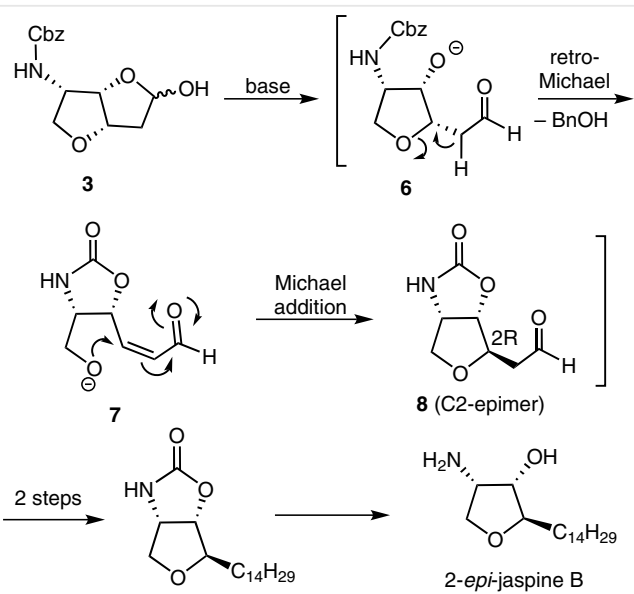

8 (C2-epimer)

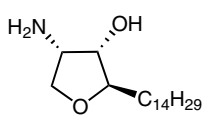

2-epi-jaspine B

Scheme 3 C2-Epimerization: A plausible pathway (as suggested by Davies) ${ }^{6 c}$

However, a more recent publication by Kim and coworkers $^{7 \mathrm{k}}$ added further intrigue to the overall scenario regarding our synthesis of jaspine B reported above, and the subsequent observations by Davis. In their study pursuing the total synthesis of jaspine B and its 2-epi analogue, Kim's group utilized a phytosphingosine-derived common precursor I to selectively obtain either the all-syn-substituted bicyclic oxazolidinone intermediate $\mathbf{5}$, or the corresponding 2-epi analogue 9 (Scheme 4) thereof. ${ }^{7 \mathrm{k}}$ Subsequent oxazolidinone ring cleavage led to jaspine $\mathrm{B}$, or 2-epi-jaspine $\mathrm{B}$, respectively. Surprisingly however, upon comparing the spectral data of the above oxazolidinones with the corresponding intermediate from our previously reported synthetic route, Kim found that oxazolidinone $\mathbf{5}$ as reported by 
us was identical to the same intermediate from his study, and is significantly different from that of the C2-epimeric analogue 9. On the basis of this study, while confirming Davies' reported observation ${ }^{6 c}$ that the final product obtained during our previous synthesis was indeed the 2-epi analogue of jaspine B, Kim however reiterated that the bicyclic oxazolidinone intermediate $\mathbf{5}$ as reported by us does contain the correct $(2 S, 3 S, 4 S)$ stereocenters and could not have been a logical precursor to the 2-epi-jaspine B as obtained. ${ }^{7 \mathrm{k}}$

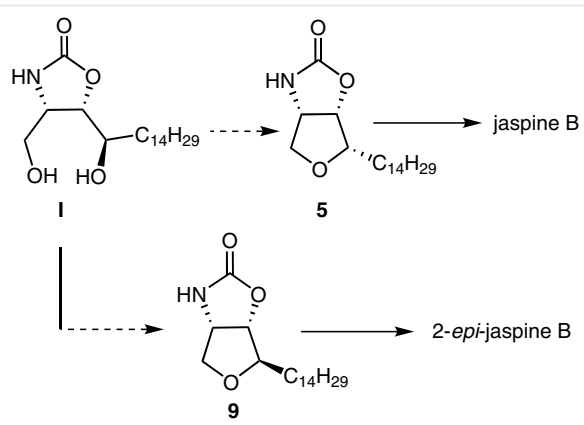

Scheme 4 Kim's synthesis of jaspine B and 2-epi-jaspine $B^{7 k}$

In view of these intriguing and apparently contradictory observations, during the present research, we decided to reinvestigate the synthetic route as employed during our previous synthesis of jaspine $B$ and try to identify the source of any anomaly.

Accordingly, by following the same protocol used in our initial synthesis (Scheme 1), starting from the bicyclic lactone $\mathbf{2}$, we repeated the same synthetic sequence involving DIBAL-H mediated reduction of the lactone to a lactol, its Wittig olefination, hydrogenation of the resulting adduct, and final hydrolytic cleavage of the cyclic carbamate. However, to our surprise, spectral and analytical data of the final product thus obtained was found to be identical to the natural jaspine B stereoisomer, and not the 2-epi analogue thereof. Similarly, the spectral data of the penultimate bicyclic oxazolidinone intermediate obtained during the synthesis was also found to be consistent with the all-syn stereoisomer $\mathbf{5}$. As the purported C2-epimerization in our previous synthesis of jaspine $B$ was suggested to have taken place under the basic reaction conditions of the Wittig olefination $\left(\mathbf{6} \rightarrow \mathbf{8}\right.$; Scheme 2 ), ${ }^{6 c}$ we also repeated the above synthetic sequence, this time performing the Wittig reaction in the presence of an excess of base (5 equiv). However, the penultimate bicyclic oxazolidinone $\mathbf{5}$, and the final jaspine B ultimately obtained from this effort were also found to be the natural all-syn stereoisomers, and not the C2-epimeric analogues thereof. The above experiments indicate that the epimeric jaspine $B$, as obtained during our previous synthetic endeavor, could not have resulted from the suspected base-mediated epimerization of the transient aldehyde intermediate 6.
The observations reported in Kim's publication, ${ }^{7 k}$ and our above reinvestigation involving the Wittig olefination sequence, therefore confirmed that, whereas the final product obtained from our initial synthesis is indeed 2-epi-jaspine $B$, the epimerization could not have been caused by base/basic conditions of the Wittig reaction process.

In view of the above conclusion, we were curious to ascertain whether, instead of base catalysis, a Lewis acid mediated epimerization ${ }^{11}$ during the lactone to lactol reduction step could have been responsible for the formation of a C-2 epimeric aldehyde intermediate, which, in turn, led to the C-2 epimeric jaspine B in our previous synthetic endeavor. We envisioned a probable mechanistic pathway, wherein, during the lactone reduction process involving this particular reaction batch, the adventitious presence of a Lewis acidic contaminant derived from impure/partially degraded DIBAL-H triggered a retro-Michael-Michael addition sequence involving the lactol-3 derived hydroxyaldehyde intermediate $\mathbf{A}$ (Scheme 5), resulting in the formation of the sterically more favorable 2,3-trans-substituted C2epimeric aldehyde $\mathbf{B}$ as shown, and ultimately leading to 2epi-jaspine B.

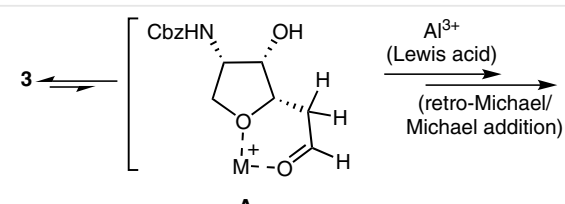

A

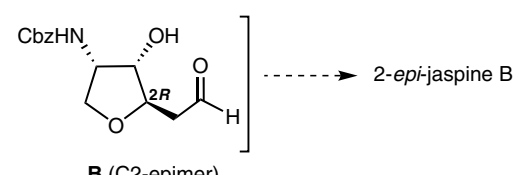

Scheme 5 A Lewis acid mediated alternative C2-epimerization pathway

As per the above rationalization, we reasoned that, during our previous attempt at the synthesis of jaspine $B$, the compound characterization data as reported for the bicyclic oxazolidinone $\mathbf{5}$ could probably have been obtained from an initial batch (standardization step) of reaction product, wherein the use of fresh/non-contaminated DIBAL-H as reducing agent avoided any C-2 epimerization. However, in moving forward with the total synthesis endeavor, in the subsequent scaled-up version of the reaction, possible use of improperly stored/degraded reagent resulted in the unforeseen formation of the epimeric aldehyde $\mathbf{B}$, and the consequently obtained 2-epi-jaspine $\mathrm{B}$ analogue.

To verify the above hypothesis, we investigated the feasibility of Lewis acid mediated epimerization of lactol 3. Unfortunately, as the original batches of DIBAL-H reagents that were used during our initial synthetic endeavors have long been exhausted, we are unable to determine the exact nature or identity of any contaminant that could have been 
responsible for the purported lactol epimerization. As an alternative, it was therefore decided to undertake the intended investigation by utilizing representative Lewis acidic reagents as available commercially. Accordingly, in separate sets of experiments, lactol $\mathbf{3}$ was treated with either $\mathrm{BF}_{3} \cdot \mathrm{Et}_{2} \mathrm{O}$ or $\mathrm{AlCl}_{3}(0.5 \mathrm{M}$ in THF). However, all of the above epimerization attempts, employing a variety of reaction conditions (varied reagent equivalence, reaction temperature, reaction time) proved unsuccessful, resulting either in the recovery of the unchanged lactol $\mathbf{3}$ or decomposition of the starting material to an intractable mixture of products.

Curiously, while the above experiments involving Lewis acid catalysis did not lead to the epimerization of lactol $\mathbf{3}$, the failure to effect epimerization of lactol $\mathbf{3}$ under basic conditions (see below) is equally baffling. Therefore, at this stage it will probably be premature to confirm (or disprove) either of the proposed pathways that could have possibly led to the epimeric jaspine B product during our initially reported synthetic endeavor (Scheme 2). Evidently, more research will have to be undertaken to elucidate the exact mechanistic pathway responsible for the unforeseen formation of the above product.

Continuing with our interest in the synthesis and medicinal chemical investigations of jaspine $B$, in the present research, we have also developed a revised reaction strategy towards circumventing any undesired C2-epimerization, and achieving a flexible total synthesis route to the above natural product and strategically designed analogues thereof.

Thus, starting from our previously employed furofuranone building block $2,{ }^{9}$ exhaustive reduction of its lactone functionality provided diol $\mathbf{1 0}$ in good yield (Scheme 6). Although the above reduction could also be achieved by using an excess of DIBAL-H alone, the recovery of the product diol was found to be poor compared with the two-step sequence involving initial DIBAL-H (1.2 equiv) reduction of the lactone to the corresponding lactol, followed by further reduction of the crude reaction product with sodium borohydride. Subsequent selective protection of the C3-C4 amino alcohol functionalities as the oxazolidine 11, and conversion of the free primary hydroxy group to the corresponding tosylate provided the desired fully protected compound $\mathbf{1 2}$ in good overall yield.

Towards installation of the required alkyl substituent at $\mathrm{C} 2$, facile $\mathrm{S}_{\mathrm{N}} 2$ displacement of the tosylate group with a dodecyl organocuprate reagent generated in situ as shown, uneventfully provided the fully protected jaspine B derivative 13. Finally, global deprotection of $\mathbf{1 3}$ under acidic conditions afforded the desired jaspine $\mathrm{B}$ as its hydrochloride salt.

\section{Structure-Activity Relationship Studies}

Having developed an efficient route to jaspine B, further utilization of the method towards SAR-targeted analogues of this natural product was next undertaken.
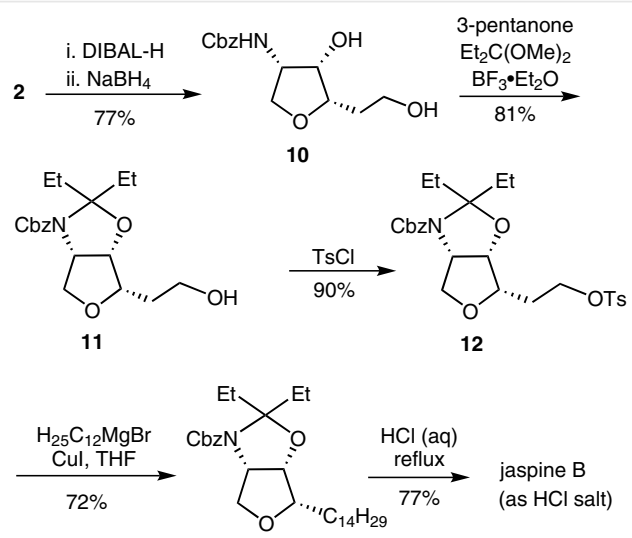

13

Scheme 6 A revised synthetic route to jaspine B

C-2-Alkyl-Modified Analogues: Jaspine B has a long lipophilic alkyl chain at the C2-position. Although some of the previous studies have targeted modification of this tetradecyl side chain, there has been no systematic study attempting to relate optimum chain length and bioactivity. Accordingly, we investigated the optimum chain length required for biological activity. Thus, replacement of the tetradecyl side chain of jaspine B with a shorter chain (propyl), a medium chain (hexyl), and a benzylic functionality as a probe for possible $\pi-\pi$ interactions at the binding pocket, were undertaken.

Syntheses of the target analogues were initiated by utilizing the advanced intermediate $\mathbf{1 2}$ from our total synthetic route. Thus, by following the same reaction protocol as in the synthesis of jaspine B, displacement of tosylate $\mathbf{1 2}$ with alkyl-magnesiocuprates generated in situ as shown, afforded the corresponding C2-alkylated analogues 14a-c (Scheme 7) in good yields. Subsequent one-pot removal of both the protecting groups under acidic conditions provided the desired C2-alkyl chain modified analogues 15a-c as hydrochloride salts.

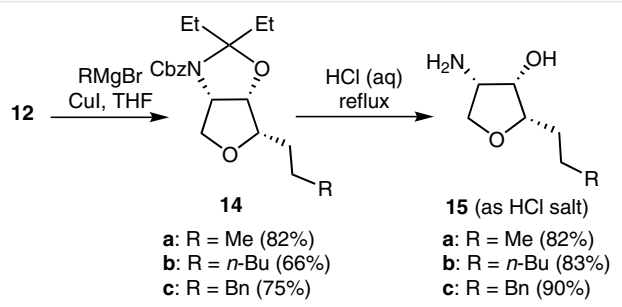

Scheme 7 Syntheses of C2-alkyl analogues of jaspine B

C-2-Ether Analogues: The natural tetradecyl side chain of jaspine $B$ renders this molecule highly lipophilic $(C \log P=6.21)$ and 'non-drug-like'.12 Aiming to modulate the lipophilicity of the above substituent, we investigated analogues wherein a methylene group in the C2-alkyl chain was subjected to bioisosteric replacement with a more po- 
lar oxygen functionality. It was reasoned that, in addition to increased polarity of the intended analogues, the $\mathrm{H}$-bond acceptor oxygen atom in the side chain could also be a potential site for binding interactions at the target-binding pocket.

Accordingly, by utilizing the strategically protected tetrahydrofuran intermediate $\mathbf{1 1}$ from our total synthesis, deprotonation of the primary hydroxyl group and subsequent O-alkylation with a representative set of three different alkyl halides, led to the formation of the corresponding ether analogues 16a-c (Scheme 8) in good yields. In a subsequent two-step deprotection protocol, initial hydrolytic cleavage of the oxazolidine ring providing the $\mathrm{N}$-Cbz-protected amino alcohols $\mathbf{1 7 a}-\mathbf{c}$, followed by reductive removal of the amine protecting group, provided the desired C2alkyloxyalkyl analogues $\mathbf{1 8 a - c}$ in good overall yields.

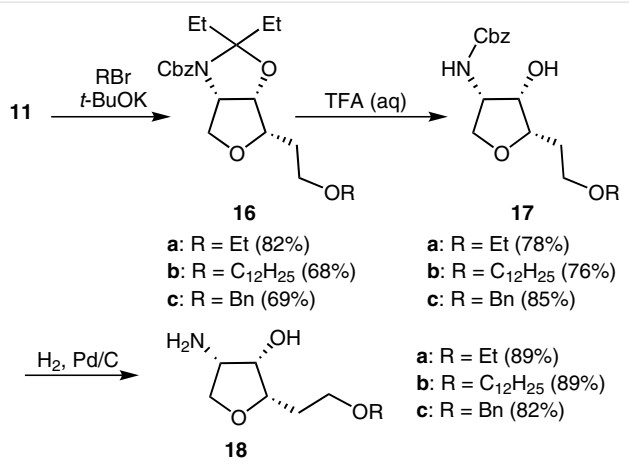

Scheme 8 Syntheses of C2-ether analogues of jaspine B

C-2-Alkylamine Analogues: In continued studies aimed at modification of the lipophilic C2-alkyl chain of jaspine B, bioisosteric replacement of one of the side chain methylene groups with an amine $(\mathrm{NH})$ moiety was next undertaken. As with the ether analogues described above, it is expected that, in addition to imparting increased hydrophilicity, the amine moiety thus introduced in the side chain could also provide a favorable tool towards probing potential H-bond interactions (both as donor and acceptor) with appropriate amino acid residues at the enzyme binding pocket.

Starting from the bicyclic lactol intermediate $\mathbf{3}$, the target analogues were synthesized by following a concise and efficient protocol as described below. Subjecting lactol 3 to standard reductive amination with a select set of primary amines in the presence of sodium triacetoxyborohydride provided the corresponding C2-alkylamino tetrahydrofuran derivatives 19a-c (Scheme 9) in good yields.

Subsequent hydrolytic removal of the Cbz-protecting group uneventfully resulted in the desired C2-alkylamine substituted jaspine B analogues 20a-c as the corresponding $\mathrm{HCl}$ salts.

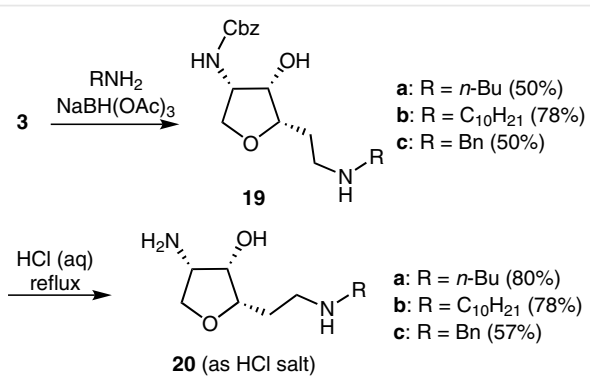

Scheme 9 Syntheses of C2-alkylamine analogues of Jaspine B

C-4-Guanidine Analogue: Except for a surprisingly few reports involving modification of the C4-amine of jaspine $\mathrm{B}$, there have been no SAR studies to determine the role of the above amine in the biological activity of this cytotoxic natural product. We therefore carried out strategic modifications of the C4-amine and evaluated the effect on biological activity.

In classical medicinal chemical approaches, guanidine motifs are often introduced as strategic alternatives for amine functional groups. In addition to strong $\mathrm{H}$-bond forming capabilities, the higher basicity and increased affinity for ionic interactions with appropriate counter anions at enzyme binding pockets render the guanidine moiety a preferred replacement for amine groups in bioactive molecules. Thus, with the aim of probing or modulating the possible biological role of the C4-amine of jaspine B in ionic, or salt-bridge forming binding interactions, we investigated the synthesis of the corresponding C4-guanidine analogue of jaspine B 22 (Scheme 10).

Thus, starting from jaspine $B$, as obtained from our total synthesis, its reaction with a known guanidine transfer reagent ${ }^{13}$ under standard conditions cleanly provided the corresponding Boc-protected guanidine derivative $\mathbf{2 1}$ (Scheme $10)$. Removal of the Boc-protecting groups with trifluoroacetic acid resulted in the desired C4-guanidino jaspine B analogue $\mathbf{2 2}$ (as the TFA salt).

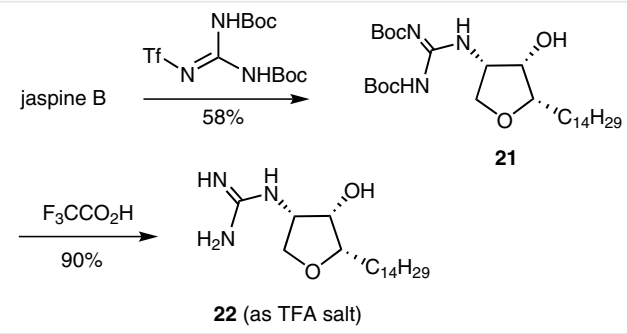

Scheme 10 Synthesis of C4-guanidino jaspine B analogue

C4-Azide Analogue: Continuing with the investigation of further modified analogues at the C4-position, conversion of the C4-amine of jaspine B into a polar and linear azide moiety was next undertaken. Accordingly, in a one-step process, reaction of jaspine $B$ with freshly prepared triflic 
azide resulted in a straightforward diazotransfer reaction forming the desired C4-azido jaspine B analogue 23 (Scheme 11).

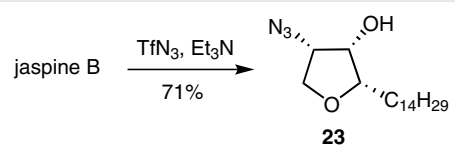

Scheme 11 Synthesis of C4-azido jaspine B analogue

C4-Triazole Analogues: Having an easy access to the C4azido jaspine $B$ analogue from the above synthetic route also created the opportunity to investigate replacement of the amine group of jaspine $B$ with a biologically relevant triazole motif. Accordingly, installation of the target triazole group at the C4-position of jaspine B was undertaken by employing the known azide-alkyne cycloaddition protocol. ${ }^{14}$ Thus, subjecting azido analogue 23 to a standard $\mathrm{Cu}(\mathrm{I})$ catalyzed 1,3-dipolar cycloaddition with 1-pentyne led to the regioselective formation of the corresponding 4-(1,4disubstituted triazolo)jaspine B analogue $\mathbf{2 4}$ (Scheme 12).

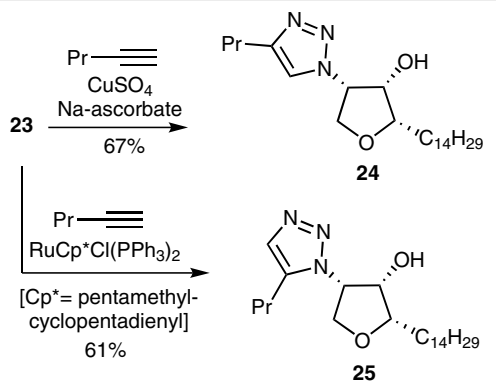

Scheme 12 Syntheses of C4-triazolo jaspine B analogues

Similarly, by employing Fokin's method, ${ }^{15}$ 1,3-dipolar cycloaddition of the azide $\mathbf{2 3}$ with 1-butyne in the presence of catalytic RuCp ${ }^{*} \mathrm{Cl}\left(\mathrm{PPh}_{3}\right)_{2}$ afforded the regioisomeric 4(1,5-disubstituted triazolo)jaspine B analogue 25 (Scheme 12).

To determine the effects of the described structural modifications on cytotoxic activity, all 13 jaspine $B$ analogues synthesized during the present study were evaluated against murine B16 melanoma cells. Jaspine B obtained from the present total synthetic route was also included as a reference in this assay (see the experimental section for assay details). As seen from Table 1, the synthetic jaspine B exhibited a dose-dependent cytotoxicity comparable to that of the natural product $\left(\mathrm{IC}_{50}=0.56 \mu \mathrm{M}\right){ }^{3}$ whereas, in an interesting trend, it was observed that shortening of the tetradecyl side chain of the natural product to a hexyl analogue (15b) retained substantial activity; further shortening to a propyl side chain (15a), or incorporation of a benzylic moiety (15c) resulted in significant loss of activity.
Table 1 Evaluation of Cytotoxic Activities of Jaspine B and Analogues against Murine B16 Melanoma Cells

\begin{tabular}{lllclc}
\hline Entry & Compound & $\mathrm{IC}_{50}(\mu \mathrm{M})$ & Entry & Compound & $\mathrm{IC}_{50}(\mu \mathrm{M})$ \\
\hline 1 & jaspine B & 0.56 & 8 & $20 \mathrm{a}$ & $>25$ \\
2 & $\mathbf{1 5 a}$ & $>25$ & 9 & $20 \mathrm{~b}$ & 1.7 \\
3 & $\mathbf{1 5 b}$ & 3.3 & 10 & $20 \mathrm{c}$ & $>25$ \\
4 & $\mathbf{1 5 c}$ & $>25$ & 11 & 22 & 10.1 \\
5 & $\mathbf{1 8 a}$ & $>25$ & 12 & 23 & $>25$ \\
6 & $\mathbf{1 8 b}$ & 2.04 & 13 & 24 & $>25$ \\
7 & $\mathbf{1 8 c}$ & $>25$ & 14 & 25 & $>25$ \\
\hline
\end{tabular}

Notably, the CLogP value $(1.979)^{16}$ of the C2-hexyl analogue 15b indicates a substantial improvement in its hydrophilic character compared with that of the parent jaspine $B$ (CLogP 6.21). In the C2-ether series involving bioisosteric replacement of an internal methylene group with oxygen, the long chain alkyloxy analogue $\mathbf{1 8 b}$ retained substantial activity, while also improving the hydrophilicity (CLogP 4.81 ) to a reasonable extent. However, the corresponding shorter chain (18a), or the benzyloxy (18c) analogues were devoid of cytotoxic activity. Similarly, in the C2-alkylamine series, the long chain alkyl amine derivative $\mathbf{2 0 b}$ is among the most active analogues synthesized, with significantly improved hydrophilic character (CLogP 3.47) compared with jaspine B. The other congeners in this series (20a and 20c) were however inactive. Modification of the C4-amine of jaspine $B$ to the corresponding guanidine analogue 22 resulted in an analogue with partially retained activity, whereas the C4-azide (23) and triazole-modified analogues (24 and 25) were inactive.

The above results indicate that the highly lipophilic C2tetradecyl side-chain of jaspine B is not necessarily an essential requirement for biological activity. Its replacement with a somewhat shorter C2-alkyl substituent, or bioisosteric incorporation of more polar entities in the chain, could provide a strategic means of obtaining jaspine $B$ analogues with improved 'drug-like' characteristics. However, the C4-amine group of this natural product appears to play an important role in its cytotoxic activity, and is apparently intolerant of any modifications.

In conclusion, an efficient and practical total synthetic route to jaspine $B$ has been developed during the present research. Flexibility of the above method towards strategic structural modifications has also provided easy access to a number of unique jaspine $\mathrm{B}$ analogues, allowing hitherto unreported SAR investigations. The studies also demonstrated a viable strategy towards modification of the highly lipophilic C2-alkyl chain of the parent natural product to more polar (hydrophilic) analogues with improved 'druglike' characteristics. The results from these studies are expected to provide useful directions towards the future design and development of further improved analogues based 
on the jaspine B structural lead. Simultaneously to the above studies, a previously reported synthetic route to jaspine B from our group has also been reinvestigated to help clarify some conflicting stereochemical issues. Although the exact mechanistic pathway leading to the formation of an unexpected epimeric product during our previous synthetic endeavor remains unclear, the above reinvestigation has confirmed the utility of our initially reported route in the stereoselective synthesis of enantiopure natural jaspine B.

All of the solvents and reagents used were obtained commercially and used as such unless noted otherwise. Moisture- or air-sensitive reactions were conducted under argon atmosphere in oven-dried $\left(120^{\circ} \mathrm{C}\right)$ glass apparatus. Diethyl ether and THF were distilled from sodium benzophenone ketyl, and dichloromethane was distilled over calcium hydride, prior to use. Solvents were removed under reduced pressure by using standard rotary evaporators. Flash column chromatography was carried out using Silica gel 60 (230-400 mesh), while thin-layer chromatography (tlc) was carried out on Silica Gel HLF, precoated glass plates. All yields reported refer to isolated material judged to be homogeneous by TLC and NMR spectroscopy. Optical rotations (at $589 \mathrm{~nm}$ ) were measured at r.t. with an AUTOPOL IV Model automatic polarimeter. A Shimadzu FTIR-8400S instrument was used to record IR spectra. ${ }^{1} \mathrm{H}$ and ${ }^{13} \mathrm{C}$ NMR spectra were recorded with Bruker DRX $400 \mathrm{MHz}$, Bruker DRX $500 \mathrm{MHz}$, or Avance AV-III $500 \mathrm{MHz}$ spectrometers. Unless noted otherwise, NMR spectra were recorded with the chemical shifts $(\delta)$ reported in ppm relative to $\mathrm{Me}_{4} \mathrm{Si}$ (for ${ }^{1} \mathrm{H}$ ) and $\mathrm{CDCl}_{3}$ (for ${ }^{13} \mathrm{C}$ ) as internal standards, respectively. Mass spectra were obtained with a ZAB HS mass spectrometer (VG Analytical Ltd., Manchester, U.K.) equipped with a 11/250 data system. Fast-atom bombardment mass spectrometry (FAB-MS) experiments were performed with a Xenon gun operated at $8 \mathrm{KeV}$ energy and $0.8 \mathrm{~mA}$ emission. Fast-atom bombardment high-resolution mass spectra [FAB-HRMS (ESI-TOF)] were recorded at 1:10,000 resolution analyzer mode (MCA). High-resolution mass spectrometry (HRMS) and FAB spectra were obtained either with a VG instrument ZAB double-focusing mass spectrometer, or with a LCT Premier Spectrometer.

\section{$(2 S, 3 S, 4 S)-4-N$-Benzyloxycarbonyl-3-hydroxy-4-(2-hydroxyeth- yl)tetrahydrofuran (10)}

Step 1: To a stirred solution of bicyclic lactone $2^{9}(1.5 \mathrm{~g}, 5.4 \mathrm{mmol})$ in anhydrous dichloromethane $(25 \mathrm{~mL})$ at $-78{ }^{\circ} \mathrm{C}$, was added DIBAL-H (1 $\mathrm{M}$ in toluene, $6.5 \mathrm{~mL}, 6.5 \mathrm{mmol}$ ) dropwise over $10 \mathrm{~min}$. After stirring for another $1.5 \mathrm{~h}$ at the same temperature, the reaction was quenched by adding $\mathrm{MeOH}(1.5 \mathrm{~mL})$ and allowed to attain r.t. To the resulting solution, EtOAc $(40 \mathrm{~mL})$ and saturated aq sodium potassium tartarate $(10 \mathrm{~mL})$ were added and the mixture was stirred for $1 \mathrm{~h}$. The organic layer was separated, and the aqueous layer was extracted with EtOAc $(3 \times 25 \mathrm{~mL})$. The combined extract was dried over anhydrous $\mathrm{Na}_{2} \mathrm{SO}_{4}$, filtered, and the filtrate was concentrated on a rotary evaporator to obtain the crude product ( $1.55 \mathrm{~g}$ ), which was used as such for the next reaction.

Step 2: The product from step 1 ( $1.5 \mathrm{~g})$ was dissolved in EtOH $(20 \mathrm{~mL})$, the solution was cooled to $0{ }^{\circ} \mathrm{C}$ (ice-bath) and powdered $\mathrm{NaBH}_{4}(420$ $\mathrm{mg}, 11.11 \mathrm{mmol}$ ) added in small portions over a period of $5 \mathrm{~min}$. After stirring at $0{ }^{\circ} \mathrm{C}$ for $15 \mathrm{~min}$, the reaction was quenched by adding crushed ice and the resulting mixture was extracted thoroughly with
EtOAc $(8 \times 30 \mathrm{~mL})$. The combined extract was dried (anhyd. $\left.\mathrm{Na}_{2} \mathrm{SO}_{4}\right)$, filtered, concentrated, and the residue was purified by column chromatography (hexanes/EtOAc, 1:1 to 1:2) to afford the pure diol 10.

Yield: $1.2 \mathrm{~g}$ (77\% over two steps); white solid; mp $105-107^{\circ} \mathrm{C} ;[\alpha]_{\mathrm{D}}$ 14.4 (c $\left.0.4, \mathrm{CH}_{3} \mathrm{OH}\right)$.

${ }^{1} \mathrm{H}$ NMR (500 MHz, $\mathrm{CDCl}_{3}$ ): $\delta=1.71-2.10(\mathrm{~m}, 2 \mathrm{H}), 2.25$ (br s, $1 \mathrm{H}$, exch. $\mathrm{D}_{2} \mathrm{O}$ ), 3.37 (br s, $1 \mathrm{H}$, exch. with $\mathrm{D}_{2} \mathrm{O}$ ), $3.66(\mathrm{t}, J=10 \mathrm{~Hz}, 1 \mathrm{H}$ ), 3.67-3.75 (m, $1 \mathrm{H}), 3.85-3.95$ (br s, $1 \mathrm{H}), 3.96-4.12(\mathrm{~m}, 2 \mathrm{H}), 4.21$ (s, $1 \mathrm{H}), 4.35-4.50$ (m, $1 \mathrm{H}$ ), 5.12 (s, $2 \mathrm{H}$ ), 5.53 (br s, $1 \mathrm{H}$, exch. $\left.\mathrm{D}_{2} \mathrm{O}\right), 7.30$ $7.45(\mathrm{~m}, 5 \mathrm{H})$.

${ }^{13} \mathrm{C}$ NMR $\left(125.8 \mathrm{MHz}, \mathrm{CDCl}_{3}\right): \delta=31.2,53.9,59.5,66.9,69.9,71.4$, 81.9, 128.1, 128.2, 128.6, 136.3, 158.0.

HRMS (ESI): $m / z$ [M $+\mathrm{H}]^{+}$calcd for $\mathrm{C}_{14} \mathrm{H}_{20} \mathrm{NO}_{5}$ : 282.1341: found: 282.1334.

(3aS,6S,6aS)-Benzyl-2,2-diethyl-6-(2-hydroxyethyl)tetrahydrofuro[3,4-d]oxazole-3(2H)-carboxylate (11)

An ice-cooled mixture of diol $\mathbf{1 0}(2 \mathrm{~g}, 7.1 \mathrm{mmol})$, 3-pentanone (12 $\mathrm{mL})$, and freshly prepared 3,3-dimethoxypentane ${ }^{17}(20 \mathrm{~mL})$ was treated with a catalytic amount of $\mathrm{BF}_{3} \cdot \mathrm{OEt}_{2}(0.1 \mathrm{~mL})$. After stirring the resulting solution at the same temperature for $3 \mathrm{~h}$, the reaction was quenched with triethylamine $(0.5 \mathrm{~mL})$ and concentrated under vacuum. The crude residue was purified by flash chromatography (hexanes/EtOAc, 4:1 to 1:1), to afford the corresponding oxazolidine derivative 11.

Yield: $2 \mathrm{~g}$ (81\%); light-yellow viscous liquid; $[\alpha]_{\mathrm{D}} 71.1\left(c 1.8, \mathrm{CH}_{2} \mathrm{Cl}_{2}\right)$.

${ }^{1} \mathrm{H}$ NMR $\left(500 \mathrm{MHz}, \mathrm{CDCl}_{3}\right): \delta$ (mixture of rotamers) $=0.71-0.92(\mathrm{~m}$, $6 \mathrm{H}), 1.66-2.21(\mathrm{~m}, 7 \mathrm{H}), 3.55-3.73(\mathrm{~m}, 2 \mathrm{H}), 3.74-3.91(\mathrm{~m}, 2 \mathrm{H}), 4.01$ and $4.18(2 \times \mathrm{m}, 1 \mathrm{H}), 4.41-4.71(\mathrm{~m}, 2 \mathrm{H}), 5.05-5.21(\mathrm{~m}, 2 \mathrm{H}), 7.25-$ $7.45(\mathrm{~m}, 5 \mathrm{H})$.

${ }^{13} \mathrm{C}$ NMR $\left(125.8 \mathrm{MHz}, \mathrm{CDCl}_{3}\right): \delta$ (mixture of rotamers) $=7.4,8.1,29.3$, 29.6, 30.3, 30.8, 30.9, 31.0, 60.7, 60.8, 62.8, 64.0, 66.7, 67.4, 73.3, 73.8, $80.9,81.5,81.9,82.0,101.6,102.4,127.7,128.0,128.1,128.2,128.6$, $136.1,136.5,151.6,152.9$.

HRMS (ESI): $m / z$ [M $+\mathrm{Na}]^{+}$calcd for $\mathrm{C}_{19} \mathrm{H}_{27} \mathrm{NO}_{5} \mathrm{Na}$ : 372.1787: found: 372.1778.

(3aS,6S,6aS)-Benzyl-2,2-diethyl-6-[2-(tosyloxy)ethyl]tetrahydrofuro[3,4-d]oxazole-3(2H)-carboxylate (12)

To an ice-cooled solution of the oxazolidine alcohol 11 (2 g, 5.73 $\mathrm{mmol})$ in anhydrous dichloromethane $(30 \mathrm{~mL})$ were added $p$-toluenesulfonyl chloride $(9.85 \mathrm{~g}, 9 \mathrm{mmol})$, pyridine $(0.9 \mathrm{~mL}, 11.1 \mathrm{mmol})$, and a catalytic amount of 4-DMAP (30 mg). After stirring the resulting solution at r.t. for $48 \mathrm{~h}$, the reaction was quenched with $10 \%$ aq $\mathrm{HCl}$ $(50 \mathrm{~mL})$. The organic layer was separated, and the aqueous layer was extracted with dichloromethane $(50 \mathrm{~mL})$. The combined organic extract was washed with brine $(50 \mathrm{~mL})$, dried over anhydrous $\mathrm{Na}_{2} \mathrm{SO}_{4}$, filtered, and concentrated under vacuum. Purification of the crude residue by flash chromatography (hexanes/EtOAc, 4:1 to 2:1) afforded the pure tosylate $\mathbf{1 2}$.

Yield: $2.6 \mathrm{~g}$ (90\%); light-yellow viscous liquid; $[\alpha]_{\mathrm{D}} 48.8$ (c 0.62 , $\mathrm{CH}_{2} \mathrm{Cl}_{2}$ ).

${ }^{1} \mathrm{H}$ NMR (400 MHz, $\left.\mathrm{CDCl}_{3}\right): \delta$ (mixture of rotamers) $=0.73-0.90(\mathrm{~m}$, $6 \mathrm{H}), 1.61-2.21(\mathrm{~m}, 6 \mathrm{H}), 2.47(\mathrm{~s}, 3 \mathrm{H}), 3.41-3.60(\mathrm{~m}, 2 \mathrm{H}), 3.94$ and $4.21(2 \times \mathrm{d}, J=8.2 \mathrm{~Hz}$ and $10.0 \mathrm{~Hz}, 1 \mathrm{H}), 4.14-4.29(\mathrm{~m}, 2 \mathrm{H}), 4.46-4.60$ (m, $2 \mathrm{H}), 5.05-5.21(\mathrm{~m}, 2 \mathrm{H}), 7.31-7.43(\mathrm{~m}, 7 \mathrm{H}), 7.81(\mathrm{~d}, J=8.24 \mathrm{~Hz}$, $2 \mathrm{H})$. 
${ }^{13} \mathrm{C}$ NMR $\left(125.8 \mathrm{MHz}, \mathrm{CDCl}_{3}\right): \delta=7.4,8.0,21.6,28.0,29.1,29.6,30.1$, 30.9, 63.0, 64.1, 66.7, 67.4, 68.0, 73.1, 73.7, 80.7, 101.5, 102.3, 127.7, $127.9,128.0,128.1,128.2,128.4,128.6,130.0,132.9,136.1,136.5$, $144.8,151.6,152.9$.

HRMS (ESI): $m / z[M+\mathrm{H}]^{+}$calcd for $\mathrm{C}_{26} \mathrm{H}_{34} \mathrm{NO}_{7} \mathrm{~S}$ : 504.2056; found: 504.2089.

\section{(3aS,6S,6aS)-Benzyl-2,2-diethyl-6-tetradecyltetrahydrofuro[3,4-d] oxazole-3(2H)-carboxylate (13)}

To a cooled mixture $\left(-78^{\circ} \mathrm{C}\right)$ of tosylate $12(250 \mathrm{mg}, 0.5 \mathrm{mmol})$ and finely powdered CuI (190 mg, $1 \mathrm{mmol})$ in anhydrous THF $(8 \mathrm{~mL})$ was added dodecylmagnesiumbromide $\left(1 \mathrm{M}\right.$ in $\left.\mathrm{Et}_{2} \mathrm{O}, 3.4 \mathrm{~mL}, 3.4 \mathrm{mmol}\right)$ dropwise over a period of $10 \mathrm{~min}$. After stirring at $-78{ }^{\circ} \mathrm{C}$ for $30 \mathrm{~min}$, the reaction mixture was warmed to $0{ }^{\circ} \mathrm{C}$ (ice-bath) and stirring was continued for $1.5 \mathrm{~h}$. The reaction was quenched with sat. $\mathrm{NH}_{4} \mathrm{Cl}(5$ $\mathrm{mL})$ and extracted with EtOAc $(5 \times 25 \mathrm{~mL})$. The combined extract washed sequentially with water and brine, dried over anhydrous $\mathrm{Na}_{2} \mathrm{SO}_{4}$, filtered, and the solvent was removed under vacuum. Purification of the crude residue by flash chromatography (hexanes/EtOAc, 9:1) afforded the fully protected jaspine B derivative 13.

Yield: $180 \mathrm{mg}$ (72\%); light-yellow viscous liquid; $[\alpha]_{\mathrm{D}} 65.7$ (c 0.6, $\mathrm{CH}_{2} \mathrm{Cl}_{2}$ ).

${ }^{1} \mathrm{H}$ NMR $\left(500 \mathrm{MHz}, \mathrm{CDCl}_{3}\right): \delta$ (mixture of rotamers $)=0.81-0.95(\mathrm{~m}$, $9 \mathrm{H}), 1.15-1.48(\mathrm{~m}, 24 \mathrm{H}), 1.71-1.97(\mathrm{~m}, 5 \mathrm{H}), 1.98-2.19(\mathrm{~m}, 1 \mathrm{H})$, 3.34-3.44 $(\mathrm{m}, 1 \mathrm{H}), 3.54-3.70(\mathrm{~m}, 1 \mathrm{H}), 4.01$ and $4.09(2 \times \mathrm{d}, J=$ $10.5 \mathrm{~Hz}$ and $10.7 \mathrm{~Hz}, 1 \mathrm{H}), 4.50-4.56(2 \times \mathrm{s}, 2 \mathrm{H}), 5.06-5.22(\mathrm{~m}, 2 \mathrm{H})$, 7.30-7.46 (m, $5 \mathrm{H})$.

${ }^{13} \mathrm{C}$ NMR $\left(125.8 \mathrm{MHz}, \mathrm{CDCl}_{3}\right): \delta$ (mixture of rotamers) $=7.4,8.1,14.1$, 22.7, 26.3, 28.1, 29.4, 29.5, 29.6, 29.7, 31.9, 63.0, 64.1, 66.6, 67.4, 73.0, 73.6, 80.5, 81.1, 83.4, 83.5, 101.3, 102.1, 127.7, 128.0, 128.1, 128.2, 128.5, 128.6, 136.2, 136.6, 151.7, 153.0.

HRMS (ESI): $m / z[\mathrm{M}+\mathrm{H}]^{+}$calcd for $\mathrm{C}_{31} \mathrm{H}_{52} \mathrm{NO}_{4}$ : 502.3896; found: 502.3846 .

\section{Jaspine B Hydrochloride}

A solution of the $\mathrm{N}, \mathrm{O}$-protected jaspine B derivative $\mathbf{1 3}$ (85 mg, 0.169 $\mathrm{mmol})$ in $50 \%$ aq $\mathrm{HCl}(10 \mathrm{~mL})$ was heated at reflux for $16 \mathrm{~h}$. The reaction mixture was cooled to r.t. and extracted with $\mathrm{Et}_{2} \mathrm{O}(10 \mathrm{~mL})$ to remove any organic soluble impurities. The aqueous layer was then concentrated in a rotary evaporator and the residual oily liquid was kept under high vacuum overnight to afford the desired jaspine B hydrochloride salt.

Yield: $44 \mathrm{mg}$ (77\%); white solid; $[\alpha]_{\mathrm{D}} 2.5\left(\right.$ c $\left.0.46, \mathrm{CH}_{3} \mathrm{OH}\right)$.

${ }^{1} \mathrm{H}$ NMR (400 MHz, CD $\left.{ }_{3} \mathrm{OD}\right): \delta=0.88(\mathrm{t}, J=5.6 \mathrm{~Hz}, 3 \mathrm{H}), 1.20-1.51(\mathrm{~m}$, $24 \mathrm{H}), 1.57-1.72(\mathrm{~m}, 2 \mathrm{H}), 3.66-3.73(\mathrm{~m}, 1 \mathrm{H}), 3.75-3.83(\mathrm{~m}, 1 \mathrm{H})$, 3.84-3.95 (m, $2 \mathrm{H}), 4.25$ (br s, $1 \mathrm{H}$ ).

${ }^{13} \mathrm{C}$ NMR $\left(125.8 \mathrm{MHz}, \mathrm{CD}_{3} \mathrm{OD}\right): \delta=14.4,23.8,29.7,30.5,30.7,30.8$, 30.9, 33.1, 54.1, 69.0, 71.0, 84.4.

HRMS (ESI): $m / z[M+\mathrm{H}]^{+}$calcd for $\mathrm{C}_{18} \mathrm{H}_{38} \mathrm{NO}_{2}$ : 300.2903; found: 300.2879 .

\section{N,O-Protected C2-Alkyl Analogues 14a-c; General Procedure}

To a cooled mixture $\left(-78{ }^{\circ} \mathrm{C}\right)$ of tosylate 12 (1 equiv) and finely powdered $\mathrm{CuI}$ (2 equiv) in anhydrous THF $(8 \mathrm{~mL})$ was added the respective Grignard reagent ( 7 equiv) dropwise over a period of $10 \mathrm{~min}$. After stirring at $-78{ }^{\circ} \mathrm{C}$ for $30 \mathrm{~min}$, the reaction mixture was warmed to $0{ }^{\circ} \mathrm{C}$ (ice-bath) and stirring was continued for $12-16 \mathrm{~h}$ (monitoring by
TLC). Subsequently, the reaction was quenched with sat. $\mathrm{NH}_{4} \mathrm{Cl}(5 \mathrm{~mL})$ and extracted with EtOAc $(5 \times 25 \mathrm{~mL})$. The combined extract was washed sequentially with water and brine, dried over anhydrous $\mathrm{Na}_{2} \mathrm{SO}_{4}$, filtered, and the solvent was removed under vacuum. Purification of the crude residue by flash chromatography (hexanes/EtOAc, 9:1) afforded the corresponding C2-alkyl analogues 14a-c.

(3aS,6S,6aS)-Benzyl 2,2-Diethyl-6-propyltetrahydrofuro[3,4-d]oxazole-3(2H)-carboxylate (14a)

Yield: $72 \mathrm{mg}$ (82\%); light-yellow viscous liquid; $[\alpha]_{\mathrm{D}} 90.0$ (c 1.1, $\mathrm{CH}_{2} \mathrm{Cl}_{2}$ ).

${ }^{1} \mathrm{H}$ NMR $\left(500 \mathrm{MHz}, \mathrm{CDCl}_{3}\right): \delta$ (mixture of rotamers) $=0.81-0.91(\mathrm{~m}$, $6 \mathrm{H}), 0.95-1.01(\mathrm{~m}, 3 \mathrm{H}), 1.41-1.54(\mathrm{~m}, 2 \mathrm{H}), 1.71-2.07$ (m, $6 \mathrm{H}), 3.38-$ $3.45(\mathrm{~m}, 1 \mathrm{H}), 3.59-3.69(\mathrm{~m}, 1 \mathrm{H}), 3.98-4.05(\mathrm{~m}, 0.6 \mathrm{H}), 4.06-4.15(\mathrm{~m}$, 0.4 H), 4.45-4.51 (m, 0.6 H), 4.53-4.61 (m, 1.4 H), 5.11-5.21 (m, $2 \mathrm{H})$, 7.21-7.41 (m, $5 \mathrm{H})$.

${ }^{13} \mathrm{C}$ NMR $\left(125.8 \mathrm{MHz}, \mathrm{CDCl}_{3}\right): \delta$ (mixture of rotamers) $=7.4,8.07,8.08$, 14.3, 19.6, 29.3, 29.5, 30.1, 30.2, 30.3, 30.9, 62.9, 64.1, 66.6, 67.3, 73.0, 73.5, 80.5, 83.1, 83.2, 101.3, 102.0, 127.6, 128.0, 128.1, 128.5, 128.6, $136.1,136.6,151.6,152.9$.

HRMS (ESI): $m / z[\mathrm{M}+\mathrm{H}]^{+}$calcd for $\mathrm{C}_{20} \mathrm{H}_{30} \mathrm{NO}_{4}$ : 348.2175; found: 348.2165 .

\section{(3aS,6S,6aS)-Benzyl 2,2-Diethyl-6-hexyltetrahydrofuro[3,4-d]ox-} azole-3(2H)-carboxylate (14b)

Yield: $63 \mathrm{mg}$ (66\%); light-yellow viscous liquid; $[\alpha]_{\mathrm{D}} 82.3$ (c 0.85 , $\mathrm{CH}_{2} \mathrm{Cl}_{2}$ ).

${ }^{1} \mathrm{H}$ NMR (400 MHz, $\left.\mathrm{CDCl}_{3}\right): \delta$ (mixture of rotamers) $=0.71-0.95(\mathrm{~m}$, $9 \mathrm{H}), 1.23-1.49(\mathrm{~m}, 8 \mathrm{H}), 1.70-2.40(\mathrm{~m}, 6 \mathrm{H}), 3.31-3.42(\mathrm{~m}, 1 \mathrm{H}), 3.51-$ $3.71(\mathrm{~m}, 1 \mathrm{H}), 3.91-4.01(\mathrm{~m}, 0.6 \mathrm{H}), 4.11-4.81(\mathrm{~m}, 0.4 \mathrm{H}), 4.49-4.51$ (m, 0.6 H), 4.53-4.61 (m, 1.4 H), 5.11-5.21 (m, $2 \mathrm{H}), 7.29-7.41(\mathrm{~m}$, $5 \mathrm{H})$.

${ }^{13} \mathrm{C}$ NMR $\left(125.8 \mathrm{MHz}, \mathrm{CDCl}_{3}\right): \delta$ (mixture of rotamers) $=7.4,8.1,14.1$, 22.5, 26.3, 28.1, 29.3, 29.4, 29.5, 29.7, 30.3, 30.9, 31.7, 62.9, 64.1, 66.6, $67.3,73.0,73.5,80.5,81.1,83.4,101.3,102.0,127.6,128.0,128.1$, $128.4,128.5,136.2,136.6,151.6,152.9$.

HRMS (ESI): $m / z[M+H]^{+}$calcd for $\mathrm{C}_{23} \mathrm{H}_{36} \mathrm{NO}_{4}$ : 390.2644; found: 390.2661 .

(3aS,6S,6aS)-Benzyl 2,2-Diethyl-6-(3-phenylpropyl)tetrahydrofuro[3,4-d] oxazole-3(2H)-carboxylate (14c)

Yield: $63 \mathrm{mg}$ (75\%); light-yellow viscous liquid; $[\alpha]_{\mathrm{D}} 88.4$ (c 0.57, $\mathrm{CH}_{2} \mathrm{Cl}_{2}$ ).

${ }^{1} \mathrm{H}$ NMR (400 MHz, $\left.\mathrm{CDCl}_{3}\right)$ : $\delta$ (mixture of rotamers) $=0.75-0.91(\mathrm{~m}$, $6 \mathrm{H}), 1.71-1.91(\mathrm{~m}, 7 \mathrm{H}), 1.93-2.15(\mathrm{~m}, 1 \mathrm{H}), 2.61-2.78(\mathrm{~m}, 2 \mathrm{H}), 3.35-$ $3.48(\mathrm{~m}, 1 \mathrm{H}), 3.55-3.71(\mathrm{~m}, 1 \mathrm{H}), 3.96-4.05(\mathrm{~m}, 0.6 \mathrm{H}), 4.11-4.18(\mathrm{~m}$, $0.4 \mathrm{H}), 4.45-4.51(\mathrm{~m}, 0.6 \mathrm{H}), 4.51-4.62(\mathrm{~m}, 1.4 \mathrm{H}), 5.11-5.22(\mathrm{~m}, 2 \mathrm{H})$, 7.12-7.31 (m, $10 \mathrm{H})$.

${ }^{13} \mathrm{C}$ NMR $\left(125.8 \mathrm{MHz}, \mathrm{CDCl}_{3}\right): \delta$ (mixture of rotamers) $=7.4,7.9,8.1$, 27.7, 27.8, 27.9, 28.1, 28.7, 29.0, 29.4, 29.5, 29.7, 30.3, 30.8, 35.8, 35.9, $62.9,64.1,65.2,66.6,67.3,73.0,73.6,80.5,81.1,83.2,83.2,101.3$, $102.1,125.7,125.9,126.1,126.9,127.2,127.5,127.8,127.9,128.0$, $128.1,128.2,128.3,128.4,128.5,128.6,128.7,129.3,129.5,130.5$, 136.1, 136.6, 142.2, 151.6, 152.9 .

HRMS (ESI): $m / z$ [M $+\mathrm{H}]^{+}$calcd for $\mathrm{C}_{26} \mathrm{H}_{34} \mathrm{NO}_{4}$ : 424.2488; found: 424.2492 . 


\section{C2-Alkyl Analogues 15a-c; General Deprotection Procedure}

The $\mathrm{N}, \mathrm{O}$-protected $\mathrm{C} 2$-alkyl analogues $\mathbf{1 4 a}-\mathbf{c}$ were heated at reflux in a solution of $50 \%$ aq $\mathrm{HCl}$ for $12-16 \mathrm{~h}$ (monitored by TLC). The reaction mixture was cooled to r.t. and extracted with dichloromethane (10 $\mathrm{mL}$ ) to remove any organic soluble impurities. The aqueous layer was then concentrated in a rotary evaporator and the residual oily liquid was kept under high vacuum overnight to afford the desired jaspine $B$ C2 alkyl analogues 15a-c as their hydrochloride salts.

\section{(2S,3S,4S)-4-Amino-2-propyltetrahydrofuran-3-ol Hydrochloride (15a)}

Yield: $31 \mathrm{mg}$ (82\%); colorless hygroscopic solid; $[\alpha]_{D} 7.7$ (c 0.6 , $\left.\mathrm{CH}_{3} \mathrm{OH}\right)$.

${ }^{1} \mathrm{H}$ NMR (500 MHz, $\left.\mathrm{CD}_{3} \mathrm{OD}\right): \delta=0.95-1.05(\mathrm{~m}, 3 \mathrm{H}), 1.41-1.59(\mathrm{~m}$, $2 \mathrm{H}), 1.61-1.72(\mathrm{~m}, 2 \mathrm{H}), 3.72-3.79(\mathrm{~m}, 1 \mathrm{H}), 3.81-3.88(\mathrm{~m}, 1 \mathrm{H}), 3.89-$ 3.98 (m, 2 H), 4.29 (br s, $1 \mathrm{H})$.

${ }^{13} \mathrm{C}$ NMR (125.8 MHz, $\left.\mathrm{CD}_{3} \mathrm{OD}\right): \delta=12.3,18.2,28.6,52.1,66.7,68.6$, 81.8 .

HRMS (ESI): $m / z[M+\mathrm{H}]^{+}$calcd for $\mathrm{C}_{7} \mathrm{H}_{16} \mathrm{NO}_{2}: 146.1181$; found: 146.1153.

\section{(2S,3S,4S)-4-Amino-2-hexyltetrahydrofuran-3-ol Hydrochloride (15b)}

Yield: $35 \mathrm{mg}$ (83\%); colorless hygroscopic solid; $[\alpha]_{\mathrm{D}} 5.4$ (c 1.35, $\left.\mathrm{CH}_{3} \mathrm{OH}\right)$.

${ }^{1} \mathrm{H}$ NMR (500 MHz, CD $\left.\mathrm{OD}\right): \delta=0.76-0.89(\mathrm{~m}, 3 \mathrm{H}), 1.19-1.41(\mathrm{~m}$, $8 \mathrm{H}), 1.51-1.64(\mathrm{~m}, 2 \mathrm{H}), 3.59-3.67(\mathrm{~m}, 1 \mathrm{H}), 3.68-3.77(\mathrm{~m}, 1 \mathrm{H}), 3.78-$ $3.91(\mathrm{~m}, 2 \mathrm{H}), 4.15-4.21(\mathrm{~m}, 1 \mathrm{H})$.

${ }^{13} \mathrm{C}$ NMR $\left(125.8 \mathrm{MHz}, \mathrm{CD}_{3} \mathrm{OD}\right): \delta=13.3,22.5,26.0,28.6,29.4,31.8$, 53.2, 67.8, 69.7, 83.2.

HRMS (ESI): $m / z[M+H]^{+}$calcd for $\mathrm{C}_{10} \mathrm{H}_{22} \mathrm{NO}_{2}$ : 188.1651; found: 188.1635 .

\section{(2S,3S,4S)-4-Amino-2-(3-phenylpropyl)tetrahydrofuran-3-ol Hy- drochloride (15c)}

Yield: $60 \mathrm{mg}$ (90\%); light-yellow hygroscopic solid; $[\alpha]_{\mathrm{D}} 10.4$ (c 0.86 , $\left.\mathrm{CH}_{3} \mathrm{OH}\right)$.

${ }^{1} \mathrm{H}$ NMR (500 MHz, $\left.\mathrm{CD}_{3} \mathrm{OD}\right): \delta=1.61-1.94(\mathrm{~m}, 4 \mathrm{H}), 2.61-2.81(\mathrm{~m}$, $2 \mathrm{H}), 3.75-4.11$ (m, $4 \mathrm{H}), 4.21-4.41$ (m, $1 \mathrm{H}), 7.09-7.39$ (m, $5 \mathrm{H})$.

${ }^{13} \mathrm{C}$ NMR (125.8 MHz, $\left.\mathrm{CD}_{3} \mathrm{OD}\right): \delta=29.1,29.3,36.9,54.3,69.0,70.8$, 84.2, 126.7, 129.3, 129.4, 129.7, 143.5.

HRMS (ESI): $m / z[M+H]^{+}$calcd for $\mathrm{C}_{13} \mathrm{H}_{20} \mathrm{NO}_{2}$ : 222.1494; found: 222.1475 .

\section{Carboxylates 16a-c; General O-Alkylation Procedure}

To an ice-cooled solution of the oxazolidine alcohol 11 (1 equiv) in THF ( $10 \%$ solution $\mathrm{w} / \mathrm{v}$ ) was added potassium tert-butoxide ( $1 \mathrm{M}$ in THF, 3 equiv) and the solution was stirred for $30 \mathrm{~min}$. The respective alkyl halides (1.2 equiv) were then added to the ice-cooled solution with stirring. The reaction mixture was allowed to attain r.t. and stirred for 6-16 $\mathrm{h}$ (tlc monitoring). The reaction was quenched with sat. aq $\mathrm{NH}_{4} \mathrm{Cl}$ and extracted with EtOAc (3×). The combined extract was washed with brine and dried over anhydrous $\mathrm{Na}_{2} \mathrm{SO}_{4}$. Removal of solvent under vacuum and purification of the residue by flash chromatography (EtOAc/hexanes, 1:9) afforded the corresponding C2alkyloxy analogues 16a-c.
(3aS,6S,6aS)-Benzyl 6-(2-Ethoxyethyl)-2,2-diethyltetrahydrofuro[3,4-d]oxazole-3(2H)-carboxylate (16a)

Yield: $75 \mathrm{mg}$ (82\%); light-yellow syrupy liquid; $[\alpha]_{D} 79.3$ (c 0.38 , $\left.\mathrm{CHCl}_{3}\right)$.

${ }^{1} \mathrm{H}$ NMR (500 MHz, $\left.\mathrm{CDCl}_{3}\right): \delta$ (mixture of rotamers) $=0.75-0.98(\mathrm{~m}$, $6 \mathrm{H}), 1.15-1.21(\mathrm{~m}, 3 \mathrm{H}), 1.69-1.99(\mathrm{~m}, 3 \mathrm{H}), 2.01-2.15(\mathrm{~m}, 3 \mathrm{H}), 3.45-$ 3.51 (m, $2 \mathrm{H}), 3.55-3.68(\mathrm{~m}, 4 \mathrm{H}), 3.95-4.03(\mathrm{~m}, 0.6 \mathrm{H}), 4.09-4.18(\mathrm{~m}$, 0.4 H), 4.45-4.63 (m, 2 H), 5.09-5.21 (m, 2 H), 7.29-7.41 (m, 5 H).

${ }^{13} \mathrm{C}$ NMR $\left(125.8 \mathrm{MHz}, \mathrm{CDCl}_{3}\right): \delta$ (mixture of rotamers) $=7.3,7.4,8.1$, 15.2, 28.5, 29.2, 29.6, 29.7, 30.2, 30.9, 63.0, 64.1, 66.1, 66.6, 67.3, 67.4, 67.5, 73.0, 73.6, 80.2, 80.6, 81.2, 101.3, 102.1, 127.6, 128.0, 128.5, 136.1, 136.6, 151.6, 152.9 .

HRMS (ESI): $m / z[\mathrm{M}+\mathrm{H}]^{+}$calcd for $\mathrm{C}_{21} \mathrm{H}_{32} \mathrm{NO}_{5}$ : 378.2280; found: 378.2278 .

(3aS,6S,6aS)-Benzyl 6-[2-(Dodecyloxy)ethyl]-2,2-diethyltetrahydrofuro[3,4-d] oxazole-3(2H)-carboxylate (16b)

Yield: $70 \mathrm{mg}$ (68\%); light-yellow viscous liquid; $[\alpha]_{\mathrm{D}} 59.3$ (c 0.67 , $\mathrm{CHCl}_{3}$ ).

${ }^{1} \mathrm{H}$ NMR $\left(500 \mathrm{MHz}, \mathrm{CDCl}_{3}\right)$ : $\delta$ (mixture of rotamers) $=0.81-0.95(\mathrm{~m}$, $9 \mathrm{H}), 1.21-1.41(\mathrm{~m}, 20 \mathrm{H}), 1.71-2.01(\mathrm{~m}, 3 \mathrm{H}), 1.95-2.19(\mathrm{~m}, 3 \mathrm{H})$, 3.35-3.51 (m, $2 \mathrm{H}), 3.51-3.71(\mathrm{~m}, 4 \mathrm{H}), 3.95-4.05(\mathrm{~m}, 0.6 \mathrm{H}), 4.11-$ $4.15(\mathrm{~m}, 0.4 \mathrm{H}), 4.49-4.53(\mathrm{~m}, 0.6 \mathrm{H}), 4.55-4.63(\mathrm{~m}, 1.4 \mathrm{H}), 5.09-5.21$ (m, $2 \mathrm{H}), 7.29-7.41(\mathrm{~m}, 5 \mathrm{H})$.

${ }^{13} \mathrm{C} \mathrm{NMR}\left(125.8 \mathrm{MHz}, \mathrm{CDCl}_{3}\right): \delta$ (mixture of rotamers) $=7.4,8.1,14.1$, 22.7, 25.8, 26.2, 28.5, 29.2, 29.3, 29.4, 29.5, 29.6, 29.7, 30.0, 30.3, 30.9, 31.9, 32.8, 63.0, 64.2, 66.7, 67.4, 67.6, 67.7, 71.0, 71.1, 73.0, 73.6, 80.3, 80.6, 81.2, 101.3, 102.1, 127.7, 128.0, 128.1, 128.5, 128.6, 136.2, 136.6, $151.6,152.9$.

HRMS (ESI): $m / z[M+H]^{+}$calcd for $\mathrm{C}_{31} \mathrm{H}_{52} \mathrm{NO}_{5}$ : 518.3845; found: 518.3857.

(3aS,6S,6aS)-Benzyl 6-[2-(Benzyloxy)ethyl]-2,2-diethyltetrahydrofuro[3,4-d]oxazole-3(2H)-carboxylate (16c)

Yield: $120 \mathrm{mg}$ (69\%); light-yellow viscous liquid; $[\alpha]_{\mathrm{D}} 40.4$ (c 0.55, $\mathrm{CH}_{2} \mathrm{Cl}_{2}$ ).

${ }^{1} \mathrm{H}$ NMR $\left(500 \mathrm{MHz}, \mathrm{CDCl}_{3}\right): \delta$ (mixture or rotamers) $=0.78-0.83(\mathrm{~m}$, $3 \mathrm{H}), 0.86-0.91(\mathrm{~m}, 3 \mathrm{H}), 1.71-2.11(\mathrm{~m}, 4 \mathrm{H}), 2.14-2.18(\mathrm{~m}, 3 \mathrm{H}), 3.58-$ $3.69(\mathrm{~m}, 3 \mathrm{H}), 3.98-4.12(\mathrm{~m}, 0.6 \mathrm{H}), 4.13-4.16(\mathrm{~m}, 0.4 \mathrm{H}), 4.45-4.55$ (m, $3 \mathrm{H}), 4.56-4.59$ (m, $1 \mathrm{H}), 5.11-5.21(\mathrm{~m}, 2 \mathrm{H}), 7.29-7.39$ (m, $10 \mathrm{H})$. ${ }^{13} \mathrm{C} \mathrm{NMR}\left(125.8 \mathrm{MHz}, \mathrm{CDCl}_{3}\right): \delta$ (mixture or rotamers) $=7.4,8.1,25.6$, 28.5, 29.3, 29.6, 30.3, 31.0, 61.1, 63.0, 64.2, 66.6, 67.3, 67.4, 67.9, 72.9, $73.0,80.3,80.6,81.1,101.3,102.1,127.5,127.6,128.1,28.3,128.5$, 128.6, 136.1, 136.6, 138.4, 151.6, 152.9.

HRMS (ESI): $m / z[\mathrm{M}+\mathrm{H}]^{+}$calcd for $\mathrm{C}_{26} \mathrm{H}_{34} \mathrm{NO}_{5}: 440.2437$; found: 440.2433 .

Carbamates 17a-c; General Acetonide Deprotection Procedure

An ice-cooled solution of TFA $/ \mathrm{H}_{2} \mathrm{O}$ (excess) was added to the $\mathrm{N}, \mathrm{O}-\mathrm{ox}$ azolidine C2-alkyloxy analogues 16a-c and stirred at r.t. for 3-4 h. Upon completion of reaction (monitored by TLC), the reaction mixture was neutralized by cautiously pouring into a saturated solution of $\mathrm{NaHCO}_{3}$. The resulting solution was extracted thoroughly with chloroform (5x). The combined organic extract washed with brine, dried over anhydrous $\mathrm{Na}_{2} \mathrm{SO}_{4}$, and filtered. Removal of solvent under vacuum and purification of the residue by flash chromatography afforded the acetonide deprotected C2-ether analogues 17a-c. 
Benzyl [(3S,4S,5S)-5-(2-Ethoxyethyl)-4-hydroxytetrahydrofuran3-yl]carbamate (17a)

Yield: $48 \mathrm{mg}$ (78\%); white solid; $\mathrm{mp} 90-92{ }^{\circ} \mathrm{C}$; $[\alpha]_{\mathrm{D}} 13.4$ (c 0.55 , $\left.\mathrm{CDCl}_{3}\right)$.

${ }^{1} \mathrm{H}$ NMR $\left(500 \mathrm{MHz}, \mathrm{CDCl}_{3}\right): \delta=1.11-1.31(\mathrm{~m}, 3 \mathrm{H}), 1.81-1.99(\mathrm{~m}, 1 \mathrm{H})$, 2.01-2.21 (m, $1 \mathrm{H}), 3.31-3.40(\mathrm{~m}, 1 \mathrm{H}), 3.41-3.58(\mathrm{~m}, 2 \mathrm{H}), 3.61-3.71$ (m, $2 \mathrm{H}), 3.84(\mathrm{~s}, 1 \mathrm{H}), 3.91-4.0(\mathrm{~m}, 1 \mathrm{H}), 4.01-4.09(\mathrm{~m}, 1 \mathrm{H}), 4.14(\mathrm{~s}$, $1 \mathrm{H}), 4.31-4.48(\mathrm{~m}, 1 \mathrm{H}), 5.01-5.21(\mathrm{~m}, 2 \mathrm{H}), 5.51-5.65(\mathrm{~m}, 1 \mathrm{H}), 7.29-$ $7.48(\mathrm{~m}, 5 \mathrm{H})$.

${ }^{13} \mathrm{C}$ NMR $\left(125.8 \mathrm{MHz}, \mathrm{CDCl}_{3}\right): \delta=15.0,29.9,53.8,66.7,66.8,66.9$, 69.9, 71.1, 82.1, 128.1, 128.5, 136.4, 156.2.

HRMS (ESI): $m / z[M+H]^{+}$calcd for $\mathrm{C}_{16} \mathrm{H}_{24} \mathrm{NO}_{5}$ : 310.1654; found: 310.1645 .

\section{Benzyl \{(3S,4S,5S)-5-[2-(Dodecyloxy)ethyl]-4-hydroxytetrahydro- furan-3-yl\}carbamate (17b)}

Yield: $50 \mathrm{mg}$ (76\%); white fluffy solid; $\mathrm{mp} 121-124{ }^{\circ} \mathrm{C} ;[\alpha]_{\mathrm{D}} 7.7(\mathrm{c}$ $\left.0.45, \mathrm{CHCl}_{3}\right)$.

${ }^{1} \mathrm{H}$ NMR $\left(400 \mathrm{MHz}, \mathrm{CDCl}_{3}\right): \delta=0.85-0.95(\mathrm{~m}, 3 \mathrm{H}), 1.21-1.41(\mathrm{~m}$, $20 \mathrm{H}), 1.81-1.95(\mathrm{~m}, 1 \mathrm{H}), 2.05-2.21(\mathrm{~m}, 1 \mathrm{H}), 3.33-3.51(\mathrm{~m}, 3 \mathrm{H})$, 3.55-3.68 (m, $2 \mathrm{H}), 3.87(\mathrm{~s}, 1 \mathrm{H}), 3.91-4.01(\mathrm{~m}, 1 \mathrm{H}), 4.02-4.09(\mathrm{~m}$, $1 \mathrm{H}), 4.11-4.18(\mathrm{~m}, 1 \mathrm{H}), 4.31-4.48(\mathrm{~m}, 1 \mathrm{H}), 5.14$ (s, $2 \mathrm{H}), 5.51-5.61$ (m, $1 \mathrm{H}), 7.25-7.45(\mathrm{~m}, 5 \mathrm{H})$.

${ }^{13} \mathrm{C}$ NMR $\left(125.8 \mathrm{MHz}, \mathrm{CDCl}_{3}\right): \delta=14.1,22.7,26.1,29.3,29.4,29.5$, 29.6, 29.7, 29.9, 31.9, 53.9, 66.8, 67.0, 70.0, 70.3, 71.1, 71.8, 82.2, $128.1,128.5,136.5,156.2$.

HRMS (ESI): $m / z[M+\mathrm{H}]^{+}$calcd for $\mathrm{C}_{26} \mathrm{H}_{44} \mathrm{NO}_{5}$ : 450.3219; found: 450.3225 .

Benzyl \{(3S,4S,5S)-5-[2-(Benzyloxy)ethyl]-4-hydroxytetrahydrofuran-3-yl\}carbamate (17c)

Yield: $55 \mathrm{mg}$ (85\%); white solid; $\mathrm{mp} 136-137^{\circ} \mathrm{C}$; $[\alpha]_{\mathrm{D}} 5.6$ (c 0.52, $\left.\mathrm{CHCl}_{3}\right)$.

${ }^{1} \mathrm{H}$ NMR $\left(400 \mathrm{MHz}, \mathrm{CDCl}_{3}\right): \delta=1.89-2.02(\mathrm{~m}, 1 \mathrm{H}), 2.05-2.21(\mathrm{~m}, 1 \mathrm{H})$, 3.47-3.77 (m, $4 \mathrm{H}), 3.91-4.09$ ( $\mathrm{m}, 2 \mathrm{H}), 4.11-4.21$ (m, $1 \mathrm{H}), 4.31-4.45$ (m, $1 \mathrm{H}), 4.51-4.61$ ( $\mathrm{m}, 2 \mathrm{H}), 5.13$ (br s, $2 \mathrm{H}), 5.51-5.61(\mathrm{~m}, 1 \mathrm{H}), 7.21-$ $7.41(\mathrm{~m}, 10 \mathrm{H})$.

${ }^{13} \mathrm{C}$ NMR $\left(125.8 \mathrm{MHz}, \mathrm{CDCl}_{3}\right): \delta=14.1,14.2,21.0,50.8,54.2,60.4$, 66.7, 66.8, 69.9, 71.1, 73.7, 81.9, 127.6, 127.8, 128.1, 128.4, 128.5, 128.6, 136.4, 137.1, 156.2 .

HRMS (ESI): $m / z[\mathrm{M}+\mathrm{H}]^{+}$calcd for $\mathrm{C}_{21} \mathrm{H}_{26} \mathrm{NO}_{5}$ : 372.1811; found: 372.1805 .

\section{Jaspine B C2-Ether Analogues 18a-c; General Hydrogenolysis Pro- cedure}

The $\mathrm{N}$-Cbz-protected analogues $\mathbf{1 7 a}-\mathbf{c}$ were dissolved in $\mathrm{MeOH}(1 \%$ solution $\mathrm{w} / \mathrm{v})$ and $10 \% \mathrm{Pd}-\mathrm{C}(10 \% \mathrm{wt})$ was added. The reaction mixture was flushed with hydrogen (twice), and stirred under a hydrogen atmosphere for 3-10 h (monitored by TLC). The reaction mixture was filtered through a Celite pad and the residue was washed with $\mathrm{MeOH}(3 \times)$. Removal of the combined filtrate under vacuum, and subjecting the residue to overnight drying under high vacuum provided the corresponding pure products $\mathbf{1 8 a}-\mathbf{c}$, respectively.

(2S,3S,4S)-4-Amino-2-(2-ethoxyethyl)tetrahydrofuran-3-ol (18a) Yield: $20 \mathrm{mg}$ (89\%); colorless viscous liquid; $[\alpha]_{\mathrm{D}} 8.2\left(c 1.15, \mathrm{CH}_{3} \mathrm{OH}\right)$. ${ }^{1} \mathrm{H}$ NMR $\left(400 \mathrm{MHz}, \mathrm{CD}_{3} \mathrm{OD}\right): \delta=1.05-1.21(\mathrm{~m}, 3 \mathrm{H}), 1.73-1.91(\mathrm{~m}$, $2 \mathrm{H}), 3.31-3.61$ (m, $6 \mathrm{H}), 3.79-3.87$ (m, $2 \mathrm{H}), 3.88-3.99$ (m, $1 \mathrm{H})$.
${ }^{13} \mathrm{C}$ NMR $\left(125.8 \mathrm{MHz}, \mathrm{CD}_{3} \mathrm{OD}\right): \delta=15.4,31.1,56.0,66.0,67.3,68.5$, 72.1, 73.5, 81.4.

HRMS (ESI): $m / z[M+\mathrm{H}]^{+}$calcd for $\mathrm{C}_{8} \mathrm{H}_{18} \mathrm{NO}_{3}$ : 176.1287; found: 176.1281.

\section{(2S,3S,4S)-4-Amino-2-[2-(dodecyloxy)ethyl]tetrahydrofuran-3-ol} (18b)

Yield: $25 \mathrm{mg}$ (89\%); colorless viscous liquid; $[\alpha]_{\mathrm{D}} 8.8\left(c 0.54, \mathrm{CH}_{3} \mathrm{OH}\right)$. ${ }^{1} \mathrm{H}$ NMR $\left(400 \mathrm{MHz}, \mathrm{CD}_{3} \mathrm{OD}\right): \delta=0.81-0.92(\mathrm{~m}, 3 \mathrm{H}), 1.21-1.41(\mathrm{~m}$, $18 \mathrm{H}), 1.51-1.61(\mathrm{~m}, 2 \mathrm{H}), 1.82-1.98(\mathrm{~m}, 2 \mathrm{H}), 3.33-3.46(\mathrm{~m}, 2 \mathrm{H})$, 3.52-3.60 (m, $2 \mathrm{H}$ ), 3.75-3.95 ( $\mathrm{m}, 4 \mathrm{H}), 4.22-4.30$ ( $\mathrm{m}, 1 \mathrm{H}$ ).

${ }^{13} \mathrm{C}$ NMR (125.8 MHz, $\left.\mathrm{CD}_{3} \mathrm{OD}\right): \delta=11.7,21.0,24.6,27.6,27.8,27.9$, 28.0, 30.4, 51.7, 66.0, 66.4, 68.4, 69.5, 79.0.

HRMS (ESI): $m / z[M+\mathrm{H}]^{+}$calcd for $\mathrm{C}_{18} \mathrm{H}_{38} \mathrm{NO}_{3}$ : 316.2852; found: 316.2843.

\section{(2S,3S,4S)-4-Amino-2-[2-(benzyloxy)ethyl]tetrahydrofuran-3-ol (18c)}

Yield: $21 \mathrm{mg}$ (82\%); light-yellow viscous liquid; $[\alpha]_{\mathrm{D}} 9.6$ (c 1.2, $\left.\mathrm{CH}_{3} \mathrm{OH}\right)$.

${ }^{1} \mathrm{H}$ NMR (500 MHz, $\left.\mathrm{CD}_{3} \mathrm{OD}\right): \delta=1.81-2.11(\mathrm{~m}, 2 \mathrm{H}), 3.38-3.46(\mathrm{~m}$, $1 \mathrm{H}), 3.48-3.55(\mathrm{~m}, 1 \mathrm{H}), 3.58-3.78(\mathrm{~m}, 2 \mathrm{H}), 3.81-3.93(\mathrm{~m}, 2 \mathrm{H}), 3.96-$ $4.04(\mathrm{~m}, 1 \mathrm{H}), 4.45-4.55(\mathrm{~m}, 2 \mathrm{H}), 7.21-7.30(\mathrm{~m}, 1 \mathrm{H}), 7.31-7.38(\mathrm{~m}$, $4 \mathrm{H})$.

${ }^{13} \mathrm{C}$ NMR (125.8 MHz, $\left.\mathrm{CD}_{3} \mathrm{OD}\right): \delta=27.0,53.3,65.7,69.5,70.8,71.3$, 71.7, 78.7, 126.0, 126.2, 126.7, 137.0.

HRMS (ESI): $m / z[\mathrm{M}+\mathrm{H}]^{+}$calcd for $\mathrm{C}_{13} \mathrm{H}_{20} \mathrm{NO}_{3}$ : 238.1443; found: 238.1441.

\section{C2-Alkylamine Analogues 19a-c; General Reductive Amination Procedure}

To a stirred, ice-cooled solution of the bicyclic lactol 3 ( 1 equiv) in anhydrous THF ( $10 \%$ solution w/v) was added $\mathrm{NaBH}(\mathrm{OAc})_{3}$ (1.2 equiv) followed by the respective alkyl amines (1 equiv). The reaction mixture was allowed to attain r.t. and stirring was continued for 2-3 h. Upon completion of the reaction (monitored by TLC), the reaction mixture was quenched with sat. aq $\mathrm{NaHCO}_{3}$ solution and extracted with EtOAc. The aqueous layer was saturated with solid $\mathrm{NaCl}$ and reextracted with EtOAc $(2 \times)$. The combined extracts were washed sequentially with water and brine, and dried over anhydrous $\mathrm{Na}_{2} \mathrm{SO}_{4}$. Solvent was removed under vacuum, and the crude product was purified by flash chromatography $\left(\mathrm{MeOH} / \mathrm{CH}_{2} \mathrm{Cl}_{2}+0.1 \% \mathrm{NH}_{4} \mathrm{OH}, 5: 95\right)$ affording the corresponding Cbz-protected $\mathrm{C} 2$-alkylamino tetrahydrofuran derivatives 19a-c.

Benzyl $\{(3 S, 4 S, 5 S)-5$-[2-(butylamino)ethyl]-4-hydroxytetrahydrofuran-3-yl\}carbamate (19a)

Yield: 50\%; light-brown solid; $\mathrm{mp} 113-114{ }^{\circ} \mathrm{C} ;[\alpha]_{\mathrm{D}} 18\left(\mathrm{c} 0.5, \mathrm{CHCl}_{3}\right)$. ${ }^{1} \mathrm{H}$ NMR $\left(500 \mathrm{MHz}, \mathrm{CDCl}_{3}\right): \delta=0.85-0.94(\mathrm{~m}, 3 \mathrm{H}), 1.31-1.41(\mathrm{~m}, 2 \mathrm{H})$, $1.42-1.50(\mathrm{~m}, 2 \mathrm{H}), 1.81-2.04(\mathrm{~m}, 3 \mathrm{H}), 2.51-2.75(\mathrm{~m}, 3 \mathrm{H}), 2.85-2.94$ (m, $1 \mathrm{H}), 3.61-3.70(\mathrm{~m}, 1 \mathrm{H}), 3.99-4.02(\mathrm{~m}, 1 \mathrm{H}), 4.03-4.12(\mathrm{~m}, 2 \mathrm{H})$, 4.31-4.45 (m, 1 H), 5.11 (br s, 2 H), 5.61-5.71 (m, 1 H), 7.27-7.49 (m, $5 \mathrm{H})$.

${ }^{13} \mathrm{C}$ NMR $\left(125.8 \mathrm{MHz}, \mathrm{CDCl}_{3}\right): \delta=13.9,20.3,31.7,43.2,54.2,66.7$, $70.1,70.4,82.1,128.0,128.5,136.5,156.3$.

HRMS (ESI): $m / z[M+H]^{+}$calcd for $\mathrm{C}_{18} \mathrm{H}_{29} \mathrm{~N}_{2} \mathrm{O}_{4}$ : 337.2127; found: 337.2111 
Benzyl $\{(3 S, 4 S, 5 S)-5-[2-($ dodecylamino)ethyl]-4-hydroxytetrahydrofuran-3-yl\}carbamate (19b)

Yield: $95 \mathrm{mg}$ (78\%); light-brown solid; mp 144-146 ${ }^{\circ} \mathrm{C} ;[\alpha]_{\mathrm{D}} 10.4(\mathrm{c}$ $0.5, \mathrm{CH}_{2} \mathrm{Cl}_{2}$ ).

${ }^{1} \mathrm{H}$ NMR $\left(500 \mathrm{MHz}, \mathrm{CDCl}_{3}\right): \delta=0.81-0.95(\mathrm{~m}, 3 \mathrm{H}), 1.21-1.41(\mathrm{~m}$, $15 \mathrm{H}), 1.42-1.50(\mathrm{~m}, 2 \mathrm{H}), 1.85-1.99(\mathrm{~m}, 2 \mathrm{H}), 2.52-2.70(\mathrm{~m}, 3 \mathrm{H})$, 2.81-2.95 (m, $1 \mathrm{H}), 3.60-3.71(\mathrm{~m}, 1 \mathrm{H}), 3.91-4.01(\mathrm{~m}, 1 \mathrm{H}), 4.02-4.11$ (m, 2 H), 4.31-4.41 (m, 1 H), 5.14 (br s, 2 H), 5.62-5.70 (m, 1 H), 7.31$7.49(\mathrm{~m}, 5 \mathrm{H})$.

${ }^{13} \mathrm{C}$ NMR $\left(125.8 \mathrm{MHz}, \mathrm{CDCl}_{3}\right): \delta=14.1,22.6,27.1,29.3,29.4,29.5$, 29.6, 31.8, 43.3, 49.5, 54.2, 66.7, 70.0, 70.2, 82.1, 128.1, 128.4, 136.5, 156.4 .

HRMS (ESI): $m / z[M+H]^{+}$calcd for $\mathrm{C}_{24} \mathrm{H}_{41} \mathrm{~N}_{2} \mathrm{O}_{4}: 421.3066$; found: 421.3027.

Benzyl $\{(3 S, 4 S, 5 S)-5$-[2-(benzylamino)ethyl]-4-hydroxytetrahydrofuran-3-yl\}carbamate (19c)

Yield: $140 \mathrm{mg}$ (50\%); light-brown solid; mp $157-158^{\circ} \mathrm{C} ;[\alpha]_{\mathrm{D}} 18(\mathrm{c}$ $0.5, \mathrm{CHCl}_{3}$ ).

${ }^{1} \mathrm{H}$ NMR $\left(400 \mathrm{MHz}, \mathrm{CDCl}_{3}\right): \delta=1.81-2.01(\mathrm{~m}, 2 \mathrm{H}), 2.49-2.61(\mathrm{~m}, 1 \mathrm{H})$, 2.81-2.91 (m, $1 \mathrm{H}), 3.59-3.67(\mathrm{~m}, 1 \mathrm{H}), 3.68-3.85(\mathrm{~m}, 2 \mathrm{H}), 3.91-4.15$ (m, 4 H), 4.21-4.40 (m, 1 H), 5.12 (br s, 2 H), 5.61-5.75 (m, 1 H), 7.26$7.49(\mathrm{~m}, 10 \mathrm{H})$.

${ }^{13} \mathrm{C}$ NMR $\left(125.8 \mathrm{MHz}, \mathrm{CDCl}_{3}\right): \delta=27.6,40.9,51.7,52.2,64.7,68.1$, $68.4,80.1,125.6,126.1,126.2,126.3,126.5,126.6,126.7,126.8,134.5$, 136.3, 154.2.

HRMS (ESI): $m / z[M+\mathrm{H}]^{+}$calcd for $\mathrm{C}_{21} \mathrm{H}_{27} \mathrm{~N}_{2} \mathrm{O}_{4}$ : 371.1971; found: 371.1942 .

\section{C2-Alkylamino Jaspine B Analogues 20a-c; General Procedure}

The $N$-Cbz protected alkyl amine analogues $20 \mathbf{a}-\mathbf{c}$ were heated at reflux in aqueous $6 \mathrm{M} \mathrm{HCl}$ solution (excess) for 12-16 h. Upon completion of reaction (monitored by TLC), the reaction mixture was extracted once with dichloromethane to remove any organic impurities and the aqueous layer was concentrated under vacuum. Drying of the resulting products under high vacuum overnight afforded the corresponding jaspine B C2-alkylamine analogues 20a-c as the corresponding hydrochloride salts.

\section{(2S,3S,4S)-4-Amino-2-[2-(butylamino)ethyl]tetrahydrofuran-3-ol Hydrochloride (20a)}

Yield: $32 \mathrm{mg}$ (80\%); light-brown hygroscopic solid; $[\alpha]_{\mathrm{D}} 13.6$ (c 0.44, $\left.\mathrm{CH}_{3} \mathrm{OH}\right)$.

${ }^{1} \mathrm{H}$ NMR (500 MHz, $\left.\mathrm{CD}_{3} \mathrm{OD}\right): \delta=0.95-1.05(\mathrm{~m}, 3 \mathrm{H}), 1.35-1.51(\mathrm{~m}$, $2 \mathrm{H}), 1.65-1.81(\mathrm{~m}, 2 \mathrm{H}), 1.95-2.05(\mathrm{~m}, 1 \mathrm{H}), 2.11-2.21(\mathrm{~m}, 1 \mathrm{H}), 2.93-$ $3.01(\mathrm{~m}, 2 \mathrm{H}), 3.15-3.24$ (m, $2 \mathrm{H}), 3.83-4.01$ (m, $4 \mathrm{H}), 4.35-4.46$ (m, $1 \mathrm{H})$.

${ }^{13} \mathrm{C}$ NMR (125.8 MHz, $\left.\mathrm{CD}_{3} \mathrm{OD}\right): \delta=14.0,20.9,25.5,26.1,26.9,29.3$, 30.3, 47.0, 54.2, 69.5, 71.1, 81.8.

HRMS (ESI): $m / z[M+\mathrm{H}]^{+}$calcd for $\mathrm{C}_{10} \mathrm{H}_{23} \mathrm{~N}_{2} \mathrm{O}_{2}:$ :203.1760; found: 203.1745.

\section{(2S,3S,4S)-4-Amino-2-[2-(decylamino)ethyl]tetrahydrofuran-3-ol} Hydrochloride (20b)

Yield: $43 \mathrm{mg}$ (78\%); light-brown hygroscopic solid; $[\alpha]_{\mathrm{D}} 2.8$ (c 1.12, $\left.\mathrm{CH}_{3} \mathrm{OH}\right)$.
${ }^{1} \mathrm{H}$ NMR $\left(500 \mathrm{MHz}, \mathrm{CD}_{3} \mathrm{OD}\right): \delta=0.89(\mathrm{br} \mathrm{s}, 3 \mathrm{H}), 1.30$ (br s, $\left.14 \mathrm{H}\right), 1.69$ (br s, 2 H), 1.95-2.05 (m, $1 \mathrm{H}), 2.07-2.18(\mathrm{~m}, 1 \mathrm{H}), 3.0$ (br s, $2 \mathrm{H}), 3.18$ (br s, $2 \mathrm{H}), 3.88-3.97$ (m, $4 \mathrm{H}), 4.36$ (br s, $1 \mathrm{H})$.

${ }^{13} \mathrm{C}$ NMR $\left(125.8 \mathrm{MHz}, \mathrm{CD}_{3} \mathrm{OD}\right): \delta=11.8,21.1,24.2,24.6,25.0,27.6$, 27.8, 27.9, 28.0, 30.4, 44.2, 51.5, 66.8, 68.4, 79.1.

HRMS (ESI): $m / z[M+H]^{+}$calcd for $\mathrm{C}_{16} \mathrm{H}_{35} \mathrm{~N}_{2} \mathrm{O}_{2}: 287.2699$; found: 287.2687.

(2S,3S,4S)-4-Amino-2-[2-(benzylamino)ethyl]tetrahydrofuran-3ol Hydrochloride (20c)

Yield: $40 \mathrm{mg}$ (57\%); light-brown hygroscopic solid; $[\alpha]_{\mathrm{D}}-22.7$ (c 0.43 , $\left.\mathrm{CH}_{3} \mathrm{OH}\right)$.

${ }^{1} \mathrm{H}$ NMR $\left(400 \mathrm{MHz}, \mathrm{CD}_{3} \mathrm{OD}\right): \delta=1.91-2.05(\mathrm{~m}, 1 \mathrm{H}), 2.09-2.21(\mathrm{~m}$, $1 \mathrm{H}), 3.11-3.21(\mathrm{~m}, 2 \mathrm{H}), 3.75-4.01(\mathrm{~m}, 4 \mathrm{H}), 4.12-4.28(\mathrm{~m}, 2 \mathrm{H}), 4.34$ (br s, $1 \mathrm{H}), 7.42-7.61(\mathrm{~m}, 5 \mathrm{H})$.

${ }^{13} \mathrm{C}$ NMR (125.8 MHz, $\left.\mathrm{CD}_{3} \mathrm{OD}\right): \delta=26.7,46.6,52.4,54.2,69.5,71.1$, $81.8,130.3,130.5,130.7,131.1,132.5$.

HRMS (ESI): $m / z[\mathrm{M}+\mathrm{H}]^{+}$calcd for $\mathrm{C}_{13} \mathrm{H}_{21} \mathrm{~N}_{2} \mathrm{O}_{2}$ : 237.1603; found: 237.1604.

\section{C4- $N, N^{\prime}$-Di-Boc-guanidine Jaspine B (21)}

To a stirred solution of jaspine $B(25 \mathrm{mg}, 83.19 \mathrm{mmol})$ in 1,4-dioxane $(2 \mathrm{~mL})$ at r.t., was added $N, N^{\prime}$-Di-Boc- $N^{\prime \prime}$-triflylguanidine ${ }^{13}$ (93.5 mg, $249.6 \mathrm{mmol}$ ) and triethylamine (24 mg, $249.6 \mathrm{mmol}$ ). After stirring for $6 \mathrm{~h}$, the reaction mixture was concentrated and the residue was partitioned between chloroform and water. The organic layer was separated, and the aqueous layer was extracted with $\mathrm{CHCl}_{3}(3 \times 10$ $\mathrm{mL}$ ). The combined organic extract was dried over anhydrous $\mathrm{Na}_{2} \mathrm{SO}_{4}$, solvent removed under vacuum, and the residue was purified by flash chromatography (EtOAc/hexanes, 12:88) to afford the product 21.

Yield: $24 \mathrm{mg}$ (58\%); white solid; $\mathrm{mp} 111-114^{\circ} \mathrm{C}$; $[\alpha]_{\mathrm{D}} 6.3$ (c 0.19, $\mathrm{CH}_{2} \mathrm{Cl}_{2}$ ).

${ }^{1} \mathrm{H}$ NMR $\left(500 \mathrm{MHz}, \mathrm{CDCl}_{3}\right): \delta=0.71-0.93(\mathrm{~m}, 3 \mathrm{H}), 1.21-1.39(\mathrm{~m}$, $25 \mathrm{H}), 1.48-1.54(\mathrm{~m}, 15 \mathrm{H}), 1.56-1.59(\mathrm{~m}, 2 \mathrm{H}), 1.61-1.71(\mathrm{~m}, 2 \mathrm{H})$, 1.95 (br s, $1 \mathrm{H}), 3.58-3.71(\mathrm{~m}, 1 \mathrm{H}), 3.75-3.88(\mathrm{~m}, 1 \mathrm{H}), 4.11-4.28(\mathrm{~m}$, $2 \mathrm{H}), 4.71-4.89$ (m, $1 \mathrm{H}), 8.91$ (br s, $1 \mathrm{H}), 11.48$ (br s, $1 \mathrm{H}$ ).

${ }^{13} \mathrm{C}$ NMR $\left(125.8 \mathrm{MHz}, \mathrm{CDCl}_{3}\right): \delta=14.1,22.7,28.0,28.3,28.9,29.3$, 29.4, 29.5, 29.6, 29.7, 29.8, 31.9, 54.0, 70.2, 72.1, 79.5, 82.1, 83.3, $153.0,156.2,163.5$.

HRMS (ESI): $m / z[M+H]^{+}$calcd for $\mathrm{C}_{29} \mathrm{H}_{56} \mathrm{~N}_{3} \mathrm{O}_{6}$ : 542.4169; found: 542.4123 .

\section{4-Guanidino Jaspine B (22)}

The $N, N^{\prime}$-di-Boc-analogue 21 (36 mg, $0.067 \mathrm{mmol}$ ) was dissolved in a solution of $\mathrm{CH}_{2} \mathrm{Cl}_{2}$ and TFA $(1: 1,2 \mathrm{~mL})$ and stirred at r.t. for $4 \mathrm{~h}$. The reaction mixture was concentrated under vacuum and the residual liquid was flushed with dichloromethane $(2 \times 3 \mathrm{~mL})$. The resulting residue was triturated with hot dichloromethane/hexane $(2: 1,15$ $\mathrm{mL})$. Drying of the product under high vacuum afforded the trifluoroacetate salt of C4-guanidino jaspine B (22).

Yield: $20 \mathrm{mg}$ (90\%); white solid; $[\alpha]_{\mathrm{D}} 2.2\left(c 0.01, \mathrm{CH}_{3} \mathrm{OH}\right)$.

${ }^{1} \mathrm{H}$ NMR $\left(500 \mathrm{MHz}, \mathrm{CD}_{3} \mathrm{OD}\right): \delta=0.87-0.95(\mathrm{~m}, 3 \mathrm{H}), 1.18-1.51(\mathrm{~m}$, $24 \mathrm{H}), 1.58-1.71(\mathrm{~m}, 2 \mathrm{H}), 3.55-3.71(\mathrm{~m}, 1 \mathrm{H}), 3.75-3.84(\mathrm{~m}, 1 \mathrm{H})$, 3.99-4.08 (m, $1 \mathrm{H}), 4.15-4.25(\mathrm{~m}, 2 \mathrm{H})$.

${ }^{13} \mathrm{C}$ NMR $\left(125.8 \mathrm{MHz}, \mathrm{CDCl}_{3}\right): \delta=13.0,22.2,22.3,25.7,28.7,29.0$, 29.2, 29.3, 29.4, 31.3, 31.6, 54.3, 68.7, 70.3, 78.0, 82.6, 157.2.

HRMS (ESI): $m / z[M+H]^{+}$calcd for $\mathrm{C}_{19} \mathrm{H}_{40} \mathrm{~N}_{3} \mathrm{O}_{2}$ : 342.3121; found: 342.3106. 


\section{4-Azido Jaspine B (23)}

Step 1: To an ice-cooled solution of $\mathrm{NaN}_{3}(157 \mathrm{mg}, 2.42 \mathrm{mmol})$ in water $(1 \mathrm{~mL})$ was added dichloromethane $(1 \mathrm{~mL})$, followed by freshly distilled trifluoromethanesulfonic anhydride (339 mg, $1.2 \mathrm{mmol}$ ) under vigorous stirring. After stirring for $2 \mathrm{~h}$ at $0{ }^{\circ} \mathrm{C}$, the organic phase was separated and the aqueous layer was extracted with dichloromethane $(3 \times 2 \mathrm{~mL})$. The combined organic extract was washed sequentially with saturated aqueous $\mathrm{NaHCO}_{3}$ solution, water, brine, and dried over anhydrous $\mathrm{Na}_{2} \mathrm{SO}_{4}$.

Step 2: To a solution of jaspine B hydrochloride salt ( $45 \mathrm{mg}, 0.134$ $\mathrm{mmol})$ in dichloromethane $(1 \mathrm{~mL})$ at r.t. was added triethylamine ( $40.5 \mathrm{mg}, 0.401 \mathrm{mmol}$ ). After cooling to $0{ }^{\circ} \mathrm{C}$ (ice-bath), the solution was treated with slow dropwise addition of the triflyl azide from Step 1 above. The reaction mixture was allowed to attain r.t. and stirred for $2 \mathrm{~h}$. The reaction was quenched with saturated aqueous $\mathrm{NaHCO}_{3}$ solution $(3 \mathrm{~mL}$ ) and the organic layer was separated. The aqueous layer was extracted with dichloromethane $(3 \times 3 \mathrm{~mL})$ and the combined extract was washed with brine, dried over anhydrous $\mathrm{Na}_{2} \mathrm{SO}_{4}$, and filtered. Removal of solvent under vacuum and purification of the residue by flash chromatography (EtOAc/hexanes, 1:9) afforded C4azido-jaspine B analogue 23.

Yield: $34 \mathrm{mg}$ (71\%); white solid; $[\alpha]_{\mathrm{D}} 11.8\left(\mathrm{c} 0.5, \mathrm{CHCl}_{3}\right)$.

IR (neat): 3330, 2916, 2848, $2102 \mathrm{~cm}^{-1}$.

${ }^{1} \mathrm{H}$ NMR $\left(400 \mathrm{MHz}, \mathrm{CDCl}_{3}\right): \delta=0.85-0.92(\mathrm{~m}, 3 \mathrm{H}), 1.16-1.46(\mathrm{~m}$, $24 \mathrm{H}), 1.57-1.71(\mathrm{~m}, 2 \mathrm{H}), 1.95-2.17(\mathrm{~m}, 1 \mathrm{H}), 3.73-3.92(\mathrm{~m}, 2 \mathrm{H})$, 3.95-4.04 (m, $1 \mathrm{H}), 4.09-4.26(\mathrm{~m}, 2 \mathrm{H})$.

${ }^{13} \mathrm{C}$ NMR (125.8 MHz, $\left.\mathrm{CDCl}_{3}\right): \delta=14.1,22.6,22.7,26.1,28.9,29.4$, 29.5, 29.6, 29.7, 31.6, 31.9, 63.7, 68.4, 72.5, 82.1, 125.0, 133.9.

\section{(2S,3S,4S)-4-(4-Propyl-1H-1,2,3-triazol-1-yl)-2-tetradecyltetrahy- drofuran-3-ol (24)}

To a solution of C-4-azido jaspine $\mathrm{B}(23 ; 40 \mathrm{mg}, 0.123 \mathrm{mmol})$ in $t$ $\mathrm{BuOH}$ and $\mathrm{H}_{2} \mathrm{O}(1: 1,2 \mathrm{~mL})$ was added 1-pentyne (18.4 mg, 0.27 $\mathrm{mmol}), \mathrm{CuSO}_{4}(15.4 \mathrm{mg}, 0.0984 \mathrm{mmol}$ ), and L-sodium ascorbate (10 $\mathrm{mg}, 0.0490 \mathrm{mmol}$ ). The resulting mixture was stirred at r.t. for $20 \mathrm{~h}$. Upon completion of reaction (tlc monitoring), the reaction mixture was concentrated under vacuum, and the residue was purified by flash chromatography (EtOAc/hexanes, 15:85) to afford 4-(1,4-disubstituted triazolo)jaspine B (24).

Yield: $26 \mathrm{mg}$ (67\%); white powder; $\mathrm{mp} 170-171^{\circ} \mathrm{C} ;[\alpha]_{\mathrm{D}} 14.8$ (c 0.28 , $\mathrm{CH}_{2} \mathrm{Cl}_{2}$ ).

${ }^{1} \mathrm{H}$ NMR (400 MHz, $\left.\mathrm{CDCl}_{3}\right): \delta=0.93-0.97(\mathrm{~m}, 6 \mathrm{H}), 1.19-1.41(\mathrm{~m}$, $22 \mathrm{H}$ ), 1.62-1.81 (m, $5 \mathrm{H}), 2.54-2.69$ (m, $2 \mathrm{H}$ ), 3.61 (br s, $1 \mathrm{H}$ ), 3.894.03 (m, $1 \mathrm{H}), 4.11-4.31$ (m, $2 \mathrm{H}), 4.41-4.60$ (m, $1 \mathrm{H}), 5.18-5.31$ (m, $1 \mathrm{H}), 7.43$ (s, $1 \mathrm{H})$.

${ }^{13} \mathrm{C}$ NMR $\left(125.8 \mathrm{MHz}, \mathrm{CDCl}_{3}\right): \delta=13.7,14.1,22.4,22.7,26.1,27.6$, 28.9, 29.3, 29.5, 29.6, 29.7, 31.9, 63.5, 68.5, 71.8, 83.0, 121.1, 147.7 .

HRMS (ESI): $m / z[\mathrm{M}+\mathrm{H}]^{+}$calcd for $\mathrm{C}_{23} \mathrm{H}_{44} \mathrm{~N}_{3} \mathrm{O}_{2}: 394.3434$; found: 394.3423.

\section{(2S,3S,4S)-4-(5-Propyl-1H-1,2,3-triazol-1-yl)-2-tetradecyltetrahy- drofuran-3-ol (25)}

To a stirred solution of C-4-azido jaspine B (23; $15 \mathrm{mg}, 0.046 \mathrm{mmol})$ in anhydrous THF $(2 \mathrm{~mL})$ was added chloro(pentamethylcyclopentadienyl)bis(triphenylphosphine)ruthenium(II) (3 $\mathrm{mg}, 0.004 \mathrm{mmol}$ ) and 1-pentyne (33 mg, $0.46 \mathrm{mmol}$ ). After heating the mixture to reflux for $24 \mathrm{~h}$, solvent was removed under vacuum, and the residue was purified by flash chromatography (EtOAc/hexanes, 1:4) to afford 4-(1,4-disubstituted triazolo) jaspine B 25.
Yield: $11 \mathrm{mg}$ (61\%); light-brown solid; mp $160-163{ }^{\circ} \mathrm{C} ;[\alpha]_{\mathrm{D}} 14.3$ (c $\left.0.4, \mathrm{CH}_{2} \mathrm{Cl}_{2}\right)$.

${ }^{1} \mathrm{H}$ NMR (400 MHz, $\left.\mathrm{CDCl}_{3}\right): \delta=0.81-1.0(\mathrm{~m}, 6 \mathrm{H}), 1.03-1.17(\mathrm{~m}, 4 \mathrm{H})$, 1.18-1.61 (m, 20 H), 1.51-1.91 (m, $4 \mathrm{H}), 2.68-2.79(\mathrm{~m}, 2 \mathrm{H}), 3.58-$ $3.80(\mathrm{~m}, 1 \mathrm{H}), 3.81-3.99(\mathrm{~m}, 1 \mathrm{H}), 4.01-4.32(\mathrm{~m}, 1 \mathrm{H}), 4.38-4.51(\mathrm{~m}$, $2 \mathrm{H}), 4.79-4.99$ ( $\mathrm{m}, 1 \mathrm{H}$ ), 7.41 (br s, $1 \mathrm{H}$ ).

${ }^{13} \mathrm{C}$ NMR $\left(125.8 \mathrm{MHz}, \mathrm{CDCl}_{3}\right): \delta=13.8,14.1,21.5,22.7,25.2,26.0$, 28.8, 29.4, 29.6, 29.7, 31.9, 60.4, 68.6, 72.2, 83.5, 121.4, 147.7.

HRMS (ESI): $m / z[\mathrm{M}+\mathrm{H}]^{+}$calcd for $\mathrm{C}_{23} \mathrm{H}_{44} \mathrm{~N}_{3} \mathrm{O}_{2}$ : 394.3434; found: 394.3440 .

\section{Cytotoxicity Assays}

In cytotoxicity evaluation studies, the jaspine B analogues were evaluated in murine B16 melanoma cells by using a homogeneous resazurin (Alamar Blue) assay. ${ }^{18}$ Stock solutions $(1 \mathrm{mM})$ of compounds were serially diluted in cell-culture medium (RPMI-1640 supplemented with $10 \mathrm{mM}$ L-glutamine, and $10 \%$ fetal bovine serum) across a 384-well plate, resulting in $40 \mu \mathrm{L}$ in each well. Aliquots $(40 \mu \mathrm{L})$ of cells suspended in cell-culture medium at a density of $10^{6}$ cells/well were added to the plate and incubated for $48 \mathrm{~h}$ in a humidified atmosphere $\left(37^{\circ} \mathrm{C}, 5 \% \mathrm{CO}_{2}\right)$. At the end of the incubation period, $40 \mu \mathrm{L}$ of the supernatant was removed and an equal volume of $2 \mathrm{X}$ resazurin $(200 \mathrm{mg} / \mathrm{mL})$ was added and incubated for an additional $4 \mathrm{~h}$. Conversion of resazurin into resorufin was quantified by ratiometric absorptimetry at 570/610 $\mathrm{nm}$ and plotted as a function of the concentration of compounds, from which average $\mathrm{IC}_{50}$ values were derived by conventional four-parameter logistic curve-fitting using GraphPad Prism.

\section{Supporting Information}

Supporting information for this article is available online at http://dx.doi.org/10.1055/s-0036-1588118.

\section{References}

(1) Present address: Department of Biomedical and Pharmaceutical Sciences, College of Pharmacy, Idaho State University, Pocatello, Idaho 83209, USA.

(2) Present address: Department of Medicinal Chemistry, University of Minnesota, Minneapolis, Minnesota 55455, USA.

(3) (a) Kuroda, I.; Musman, M.; Ohtani, I. I.; Ichiba, T.; Tanaka, J.; Gravalos, D. G.; Higa, T. J. Nat. Prod. 2002, 65, 1505. (b) Ledroit, V.; Debitus, C.; Lavaud, C.; Massiot, G. Tetrahedron Lett. 2003, 44, 225.

(4) Salma, Y.; Lafont, E.; Therville, N.; Carpentier, S.; Bonnafé, M.-J.; Levade, T.; Génisson, Y.; Andrieu-Abadie, N. Biochem. Pharmacol. 2009, 78, 477.

(5) (a) Yoshimitsu, Y.; Oishi, S.; Miyagaki, J.; Inuki, S.; Ohno, H.; Fujii, N. Bioorg. Med. Chem. 2011, 19, 5402. (b) Yoo, H.; Lee, Y. S.; Lee, S.; Kim, S.; Kim, T.-Y. Phytother. Res. 2012, 26, 1927.

(6) For reviews, see: (a) Martinkova, M.; Gonda, J. Carbohydr. Res. 2016, 423, 1. (b) Ballereau, S.; Baltas, M.; Génisson, Y. Curr. Org. Chem. 2011, 15, 953. (c) Abraham, E.; Davies, S. G.; Roberts, P. M.; Russell, A. J.; Thomson, J. E. Tetrahedron: Asymmetry 2008, 19, 1027.

(7) For a representative list of recent publications, see: (a) Fujiwara, T.; Liu, B.; Niu, W.; Hashimoto, K.; Nambu, H.; Yakura, T. Chem. Pharm. Bull. 2016, 64, 179. (b) Garcia, V.; Le Faouder, P.; Dupuy, A.; Levade, T.; Ballereau, S.; Genisson, Y. Chem. Biodivers. 2015, 12, 1115. (c) Martinkova, M.; Mezeiova, E.; Fabisikova, M.; 
Gonda, J.; Pilatova, M.; Mojzis, J. Carbohydr. Res. 2015, 402, 6. (d) Shelke, A. M.; Rawat, V.; Sudalai, A.; Suryavanshi, G. RSC Adv. 2014, 4, 49770. (e) Martinková, M.; Mezeiová, E.; Gonda, J.; Jacková, D.; Pomikalová, K. Tetrahedron: Asymmetry 2014, 25, 750. (f) Ghosal, P.; Ajay, S.; Meena, S.; Sinha, S.; Shaw, A. K. Tetrahedron: Asymmetry 2013, 24, 1625. (g) Jana, A. K.; Panda, G. RSC Adv. 2013, 3, 16795. (h) Dhand, V.; Chang, S.; Britton, R. J. Org. Chem. 2013, 78, 8208. (i) Santos, C.; Fabing, I.; Saffon, N.; Ballereau, S.; Genisson, Y. Tetrahedron 2013, 69, 7227. (j) Yoshimitsu, Y.; Miyagaki, J.; Oishi, S.; Fujii, N.; Ohno, H. Tetrahedron 2013, 69, 4211. (k) Bae, H.; Jeon, H.; Baek, D. J.; Lee, D.; Kim, S. Synthesis 2012, 44, 3609. (1) Zhao, M.-L.; Zhang, E.; Gao, J.; Zhang, Z.; Zhao, Y.-T.; Qu, W.; Liu, H.-M. Carbohydr. Res. 2012, 351, 126. (m) Cruz-Gregorio, S.; Espinoza-Rojas, C.; Quintero, L.; Sartillo-Piscil, F. Tetrahedron Lett. 2011, 52, 6370. (n) Rao, G. S.; Rao, B. V. Tetrahedron Lett. 2011, 52, 6076. (o) Passiniemi, M.; Koskinen, A. M. P. Org. Biomol. Chem. 2011, 9, 1774. (p) Liaveria, J.; Diaz, Y.; Matheu, M. I.; Castillon, S. Eur. J. Org. Chem. 2011, 1514. (q) Vichare, P.; Chattopadhyay, A. Tetrahedron: Asymmetry 2010, 21, 1983. (r) Rao, G. S.; Sudhakar, N.; Rao, B. V.; Basha, S. J. Tetrahedron: Asymmetry 2010, 21, 1963. (s) Salma, Y.; Ballereau, S.; Maaliki, C.; Ladeira, S.; Andrieu-Abadie, N.; Genisson, Y. Org. Biomol. Chem. 2010, 8, 3227. (t) Inuki, S.; Yoshimitsu, Y.; Oishi, S.; Fujii, N.; Ohno, H. J. Org. Chem. 2010, 75, 3831. (u) Yoshimitsu, Y.; Inuki, S.; Oishi, S.; Fujii, N.; Ohno, H. J. Org. Chem. 2010, 75, 3843. (v) Urano, H.; Enomoto, M.; Kuwahara, S. Biosci., Biotechnol., Biochem. 2010, 74, 152.

(8) For studies on the synthesis and biological evaluation of structurally modified jaspine B analogues, see: (a) Mezeiova, E.; Martinkova, M.; Stankova, K.; Fabisikova, M.; Gonda, J.; Pilatova, M.; Gonciova, G. Carbohydr. Res. 2016, 423, 70. (b) Kwon, Y.; Song, J.; Bae, H.; Kim, W.-J.; Lee, J.-Y.; Han, G.-H.; Lee, S. K.; Kim, S. Marine Drugs 2015, 13, 824. (c) Kundooru, S.; Das, P.; Meena, S.; Kumar, V.; Siddiqi, M. I.; Datta, D.; Shaw, A. K. Org. Biomol. Chem. 2015, 13, 8241. (d) Xu, J.-M.; Zhang, E.; Shi, X.-J.; Wang, Y.-C.; Yu, B.; Jiao, W.-W.; Guo, Y.-Z.; Liu, H.-M. Eur. J. Med. Chem.
2014, 80, 593. (e) Salma, Y.; Ballereau, S.; Ladeira, S.; Lepetit, C.; Chauvin, R.; Andrieu-Abadie, N.; Genisson, Y. Tetrahedron 2011, 67, 4253. (f) Ballereau, S.; Andrieu-Abadie, N.; Saffon, N.; Genisson, Y. Tetrahedron 2011, 67, 2570. (g) Jeon, H.; Bae, H.; Baek, D. J.; Kwak, Y.-S.; Kim, D.; Kim, S. Org. Biomol. Chem. 2011, 9, 7237. (h) Rives, A.; Ladeira, S.; Levade, T.; Andrieu-Abadie, N.; Genisson, Y. J. Org. Chem. 2010, 75, 7920. (i) See also ref. 7o. (j) Jayachitra, G.; Sudhakar, N.; Anchoori, R. K.; Rao, B. V.; Roy, S.; Banerjee, R. Synthesis 2010, 115.

(9) Bhaket, P.; Morris, K.; Stauffer, C. S.; Datta, A. Org. Lett. 2005, 7, 875.

(10) For the synthesis of 1, see: Bhaket, P.; Stauffer, C. S.; Datta, A. J. Org. Chem. 2004, 69, 8594 .

(11) For instances of acid-mediated epimerization in cyclic systems, involving ring-opening and recyclization, see: (a) Yamamoto, S.; Kuse, M.; Takikawa, H. Tetrahedron Lett. 2015, 56, 5808. (b) Walker, M. M.; Goodman, C. G.; Johnson, J. S. J. Org. Chem. 2014, 79, 9385. (c) Van Linn, M. L.; Cook, J. M.J. Org. Chem. 2010, $75,3587$.

(12) (a) Leeson, P. D.; Young, R. J. ACS Med. Chem. Lett. 2015, 6, 722. (b) Leeson, P. D.; Springthorpe, B. Nat. Rev. Drug Discovery 2007, 6,881 .

(13) Feichtinger, K.; Zapf, C.; Sings, H. L.; Goodman, M. J. Org. Chem. 1998, 63, 3804.

(14) (a) Tornøe, C. W.; Christensen, C.; Meldal, M. J. Org. Chem. 2002, 67, 3057. (b) Rostovtsev, V. V.; Green, L. G.; Fokin, V. V.; Sharpless, K. B. Angew. Chem. Int. Ed. 2002, 41, 2596.

(15) Boren, B. C.; Narayan, S.; Rasmussen, L. K.; Zhang, L.; Zhao, H.; Lin, Z.; Jia, G.; Fokin, V. V. J. Am. Chem. Soc. 2008, 130, 8923.

(16) All the CLogP values listed were obtained by using the ChemDraw software (version 15.1.0.144).

(17) Schmid, C. R.; Bradley, D. A. Synthesis 1992, 587.

(18) (a) Hamid, R.; Rotshteyn, Y.; Rabadi, L.; Parikh, R.; Bullock, P. Toxicol. in Vitro 2004, 18, 703. (b) Nociari, M. M.; Shalev, A.; Benias, P.; Russo, C. J. Immunol. Methods 1998, 213, 157. 